\title{
HAKKÂRILi DEVLET ADAMI VE ÂLiMLER (ABBÂSÎLER DÖNEMi)
}

\author{
White Pigeons of Aerie of Scholars From Hakkari \\ (Abbasid Period)
}

\section{Dr. Şakir GÖZüTOK}

\begin{abstract}
ÖZ
ìslâm dünyasında, sahip oldukları ilmî kurumlarla veya âlimlerle şöhret bulmuş pek çok yerleşim merkezi bulunmaktadır. Her ne kadar tarihte kendilerinden sıkça söz edilen șehirler kadar olmasa da, bulunduğu bölge itibariyle kendisinden beklenenden daha çok ilme hizmet vermiş ve âlim yetiştirmiş şehirlerden biri Hakkâri'dir. Burada söz konusu ettiğimiz âlimler Hakkârili olmakla beraber, bunların çoğu değişik şehirlerde ilim tahsil etmişlerdir. Bu çalışmamızda, Hakkârili kadın ve erkek âlimler ve onların ortaya koydukları ilmî eserler hakkında bilgi verilmeye çalışılacaktır.
\end{abstract}

Anahtar sözcükler: Hakkâri, ilim, âlimler.
ABSTRACT

There have been lots of residential units which are famous for its scientific foundations and scholars in the life of science. Hakkari is a city which has made more contributions to science and training scholars than expected in terms of its regional location, although it is not a city often mentioned with this respect in history. Even through the mentioned scholars are from Hakkari, most of them have studied in different cities. In this study, female and male scholars from Hakkari and their studies are examined and introduced.

Key words: Hakkari, Science, Scholars

\section{Giriş}

Şehirleri tanıtan tarihî kitaplarda Hakkâri, kendisine bağlı köyleri de kapsayan Cezîre bölgesinde Kürtlerin yaşadı̆̆ bir nahiye olarak gösterilmektedir.' Abbâsî Hilâfeti döneminde Hakkâri, Musul'a bağı ıir belde konumundadır. Bazı kaynaklarımızda Hakkâri, aynı zamanda İmâdiye ve Harun Kalelerinin bulunduğu ve Çölemerik beldesinin yanındaki bir yer olarak tanıtılır. Tarihçi Yâkut elHamevĩ nin bildirdiğine göre, burada yaşayan kabile "Hakkâriye" olarak bilinirdi ve dört bin civarında elleri silah tutan askerlere sahipti. Burada yaşayanların kendilerine ait özel bir mimari stilleri vardı. Burada yaşayan ahali, Buhara'dan Cezîre bölgesine kadar çoğu yerlerde muhâfızlık görevini üstlenerek geçimlerini

\footnotetext{
*Yüzüncü Yıl Üniversitesi ilâhiyat Fakültesi Felsefe ve Din Bilimleri Bölümü Din Eğitimi Anabilim Dalı.

'Şihabuddin Ebû Abdullah Yâkut b. Abdullah el-Hamevî (ö. 626/1229), Mu'cemu'l-Buldan, Daru Sadır, Beyrut, 1977, c. V, s. 408.
} 
sağlarlardı. Buradaki kalelerden birinin yöneticisi olan Harun, Mısır diyarındaki Sultanlarla yazışırdı. ${ }^{2}$ Gerçekten de ileride de bazı şahısları ele aldığımızda da görüleceği üzere Hakkârili pek çok komutan hem Zengiler hem de Eyyûbîler döneminde önemli görevler üstlenmiş ve bazı savaşlarda başarılar elde etmişlerdir.

Hakkâri'nin bir diğer adı olan Çölemerik ise, yine Hakkâriye gibi bir aşiretin adıdır ama iskân ettikleri bölgeyle anılmaktaydılar. Dolayısıyla Çölemerik, hem bir bölgenin adı hem de bu bölgede yaşayan aşirete verilen bir isimdir. Bu aşiretin aslında Emevîlerin soyundan gelen bir Arap kabilesi olduğu ve Abbâsîlerin, Emevîleri yenmesiyle birlikte bu sarp dağlara sahip bölgeye gelip yerleştikleri, Kürtlerle birlikte yaşadıklarından zamanla Kürtleştiklerine dair iddialar da mevcuttur ${ }^{3}$. Kanaatimizce bazı Hakkârili âlimlerin, "Kureşı̂" nispetiyle anılmaları da buna bir işarettir. Buradaki sığınaklar, en zorlu sığınaklardı, kaldı ki dağların bizzat kendisi güçlü bir sığınak oluşturmaktadır. Zap suyu da ayrıca burayı aşağıdan kuşatmaktadır. ${ }^{4}$ Kalkaşendî bu kabilenin üç bini aşkın bir nüfusa sahip olduklarını söyler. Moğolların ilk zamanlarında yöneticileri, Esed b. Miklân'dı, sonra yerine oğlu İmâduddin ve onun yerine de oğlu Eseduddin geçmiştir. Burada kırmızı ve sarı renkte arsenik madenî bulunurdu, değişik bölgelere bunu pazarlarlardı. Burada ayrıca lacivert taşı denilen değerli bir maden de vardı, fakat Moğol hükümdarları bunları gasp etmesin diye buradaki yerliler bunları gizli işliyorlardı. ${ }^{5}$ Bu iki madenin varlığı bu belde için yeterli geçim kaynağı sağlamaktaydı. Ayrıca hayvancılık da başka bir gelir kaynağıydı. Hakkâri'nin, Abbâsîler döneminde ilmin tahsil edildiği bir yer olduğuna dair bazı örneklerle karşılaşmaktayız. Ünlü hadis âlimlerinden biri olan Ebû Abdullah Muhammed b. Hüseyin b. Muhammed b. Mehdi ed-Darebcirdĩnin, 472/1079 senesinde Ebû Hasan Ali b. Ahmed b. Yusuf el-Kureşî el-Hakkârî̀den bizzat Hakkâri şehrinde hadis dersleri aldığına dair bilgilere sahibiz. ${ }^{6}$ Bu bilgi de erken sayılacak söz konusu dönemde Hakkâri'de önemli hadis âlimlerinin yetiştiğini göstermektedir. Hakkâri'de ilme olan iştiyak başka yerlerden bazı âlimlerin buraya gelmesini sağlamışır. Söz gelimi Ebû Abbâs Ahmed b. İsâ et-Temuzî, aslen Hakkârili olmadığ $ı$ halde, Hakkâri'ye gelerek burada öğretmenlik yapmıştır. Bu zat öğretmenliğinin yanında çoğu kez cenazelerde Kur'ân okur ve kimsesizlerle birlikte

\footnotetext{
${ }^{2}$ Ahmed Ali el-Kalkaşendî, Subhu'l-A'şâ fî Sinaati'l-inşâ, nşr. Muhammed Hüseyin Şemsuddin, Dâru'l-Fikr, 1. Baskı, Beyrut, 1987, c. IV, s. 378.

${ }^{3}$ Kalkaşendî, Subhu'l-A'şâ, c. IV, s. 376.

${ }^{4}$ Kalkaşendî, Subhu'l-A'şâ, c. IV, s. 376, 377.

${ }^{5}$ Kalkaşendî, Subhu'l-A'şâ, c. IV, s. 377.

${ }^{6}$ ibn Asâkir, Hâfız Ebû Kasım Ali b. Hasan b. Hibetullah (ö. 571/1175), Târihu Medineti Dımaşk, nşr. Muhibuddin Ebu Said Ömer b. Garâme el-Amrevî, Dâru'l-Fikr, 1. Baskı, Beyrut, 1997, c. Lll, s. $356,357$.
} 
kabirlerde otururdu. Kendisi fakih biriydi. Es'ad'dan ilim öğrenmişti. Aynı zamanda şairdi. Daha sonra Balat'a geçmiş ve orada evlenmiştir.

Ancak şunu ifade etmek gerekir ki Hakkâri, Adî b. Musâfir'in (ö. 557/1162) zamanına kadar ilim alanında herhangi bir önemli etkinliğe ve şöhrete sahip değildir. Adî b. Musâfir'in burada kurduğu zaviye bir medrese gibi işlev görmüş, hem tasavvufi ilimlerde hem de diğer dinî ilimlerde hatırı sayılır âlimler yetiştirmiştir. İslâm dünyasında ilim öğrenmek için genellikle ilim merkezlerine doğru bir hareketlilik ve seyahat daima mevcuttur. Bu sebeple bir memlekette doğan her hangi bir kişi, ilim öğrenmek için rahatlıkla başka diyarlara seyahat edebilir ve ilim öğretmek üzere de oralarda ikamet edip memleketine bir daha dönmeyebilirdi. Bu tür seyahatler genellikle şöhretli medrese veya müderrislerin bulunduğu şehirlere yapılırdı. Bu yüzden ilim dünyasında hiç durmayan ve dinmeyen sürekli bir hareketlilik mevcuttu. Bunun için çok uzun yolculukların yapıldığına şahit olmaktayız. Meselâ Muhammed b. Sâlih el-Me'afirî el-Endelusî (ö. 378/988), bugünkü isspanya'dan yola çıkarak Kazvin'e kadar gelip burada Hadis ilmini tahsil etmişti. ${ }^{8}$ Muhammed b. Abdurrahim b. Süleyman b. Rebi' el-Gırnâtî, Ispanya'nın Gırnata şehrinden yola çıkarak Kazvin'e kadar gelmiş burada ilim tahsil ettikten sonra yine Kazvin'de dersler de vermişti. ${ }^{9}$ ibn Halâs diye meşhur Endülüslü Muhammed b. Ahmed el-Kaysî (ö. 394/1004), doğuya yaptığı seyahatler esnasında 170 hocadan ders aldığını söylemektedir. ${ }^{10}$

Hakkârililerin önemli bir kısmı da, İmâduddin Zengi, daha sonra oğlu Nûreddin Zengi ve Selâhaddin Eyyûbînnin ordularında görev aldıklarından başta Kahire olmak üzere, Mısır'a yakın şehirlerde, Kudüs'te, Şam'da ve Halep gibi değişik şehirlerde yetişmişlerdir. Meselâ onlardan biri olan Emir İzzuddin Mûsek el-Hakkârî, Eyyûbî Devletinin komutanlarından biriydi. Mısır'da onun adıyla anılan kemerli bir köprü vardır." Bu şekilde devletin çeşitli kademelerinde yöneticilik yapan Hakkârili âlimlerden bazılarının geride bıraktığı eserler de mevcuttur. Öncelikle bu zatları tanıtmakla işe başlamak istiyoruz.

\footnotetext{
${ }^{7}$ İmâd el-i̇sbehânî, Harîdetu'l-Kasr ve Ceridetu'l-Asr, www.al-mostafa.com, 17.02.2011, 22.51, c. II, s. 46.

${ }^{8}$ Abdulkerim b. Muhammed er-Râfîi el-Kazvinî, et-Tedvin fî Ahbari Kazvin, nşr. Azizullah elAttaridî, Dâru'l-Kutubi'l-ilmiyye, Beyrut, 1987, c. l, s. 305.

${ }^{9}$ el-Kazvinî, et-Tedvin fi Ahbâri Kazvin, c. l, s. 318.

${ }^{10}$ Ebu'l-Velid Abdullah b. Muhammed b. Yûsuf ibnü'l-Faradî (ö. 403/1013), Târîhu Ulemâi'lEndelüs: Târihu'l-Ulemâ ve'r-Ruvât li'l-ilm bi'l-Endelüs, nşr. ibrahim el-Ebyarî, Dâru'l-Kutubi'lBenanî, 2. Baskı, Beyrut, 1989, c. ll, s. 795.

"Muhammed b. Muhammed b. Abdurezzak ez-Zubeydî, Tâcu'l-Arûs min Cevâhiri'l-Kâmûs, Dâru'l-Hidaye, c. XXVII, s. 339.
} 


\section{Hâkkarili Vali ve Komutanlar}

Yukarıda da ifade ettiğimiz gibi, aslen Hakkârili olup da çok iyi bir eğitimden geçmiş ve bu münasebetle bazı üst düzey görevler almış çok sayıda âlim mevcuttur. Bunlardan "emir" olarak komutanlık ve valilik yapanlar şunlardır:

\section{1. İsâ b. Muhammed b. İsâ Emir Ziyauddin Ebû Muhammed el-Hakkârî}

Hz. Ali'nin oğlu Hasan'ın soyundandır. Fakih bir zat ve Eyyûbî Devleti'nin önde gelen komutanlarından (emir) biriydi. Aynı zamanda Selâhaddin Eyyûbî̀nin müsteşarıydı ve kendisinin görüşlerinden asla ayrılmazdı. Cezîretu ibn Ömer'de Şafiî âlimi İmam Ebû Kasım b. Bezrî̀den fıkıh dersleri aldı ve sonra Halep'e geçti. Halep'te iken Hâfız Tâhir es-Silefî ve Hâfız Ebû Kasım ibn Asâkir'den hadis derslerini aldı ve daha sonra kendisi hadis derslerini vermeye başladı. Önceleri Halep'te Züccaciye Medresesi'nde ders almaya başladı. ${ }^{2}$ Kadı Muhammed b. Ali ve başkaları da kendisinden dersler aldılar. onun bahtının açılması, Melik Eseduddin Şirku'nun hizmetine girmesiyle başladı, önceleri Melik'in beş vakit namazlarında imamlık yapardı ve daha sonra kendisiyle birlikte Mısır'a geçti. Amcasından sonra Sultan Selâhaddin Eyyûbînnin hizmetine kendisini adadı, bunu Eseduddin ona emretmişti. Selâhaddin Eyyûbî, ona yöneticilikler vererek şanını yüceltti ve sonunda devletin en üst yöneticisi durumuna geldi. Selâhaddin Eyyûbî, Mısır'ı fethettikten sonra Kahire'deki Fatımi kadısını görevden alarak yerine ìsâ b. Muhammed el-Hakkârîyi Kahire kadısı olarak atadı. Bu zat aynı zamanda bütün Eyyûbî Devletindeki Şafîilerin kadılı̆̆ına da niyabeten bakıyordu. ${ }^{13}$ Bir defasında savaşta esir düşmüş ve Selâhaddin Eyyûbî altmış bin dinar ödeyerek karşılığında kendisini serbest bıraktırmıştır. 585/1189 yılının Zu'l-Kaade ayında Akkâ muhasarası esnasında Haçlılarla savaşırken vefat etti ve daha sonra cenazesi Kudüs'e getirilerek surların diş tarafına defnedildi. ${ }^{14}$ Selâhaddin Eyyûbî,

\footnotetext{
${ }^{12}$ Ebu'l-Abbâs Şemsuddin Ahmed b. Muhammed b. Ebî Bekr ibn Hallikân (ö. 681/1282), Vefeyâtu'l-A'yân ve Enbâu Ebnâi'z-Zaman, nşr. îhsan Abbâs, Daru Sadr, 4. Baskı, Beyrut, 2005, c. III, s. 497; ibn Kesir ed-Dımaşkî, Tabakatu'l-Fukahâi'ş-Şâfî̀yye, nşr. Ahmed Ömer Haşim ve Muhammed Zeynehum Muhammed Azib, Mektebetu's-Sekafeti'd-Diniyye, Kahire, 1993, c. II, s. 721, 722; Muhammed Ali es-Sellûbî, Selahaddîn el-Eyyûbî ve Cuhûduhu fi'l-Kadai ale'd-Devleti'lFatimiyye ve Tahriri'l-Beyti'l-Mukaddes, Dâru'l-Ma'rife, ı. Baskı, Beyrut, 2008, s. 333.

${ }^{13}$ Muhammed Ali es-Sellûbî, Selahaddun el-Eyyûbî ve Cuhuduhu, s. 191.

${ }^{14}$ Tacuddin Ebu Nasr Abdulvahhab b. Ali b. Abdilkâfi es-Subkî (ö. 771/1370), TabakatuşsŞaffîyyeti'l-Kübrâ, Nşr. Mahmud Muhammed et-Tanahî, Abdulfettah Muhammed el-Hulv, Daru ihyai'l-Kutubi'l-Arabiyye, Kahire, ts., c. VII, s. 255, 256; ibn Hallikân, Vefeyâtu'l-A'yân, c. III, s. 497; ibnu'l-Esîr Ebû Hasan Ali b. Ebi Kerem Muhammed b. Muhammed b. Ebi Kerim eşŞeybanî (ö. 630/1233), el-Kâmil fít-Târih, Nşrr. Ebu'l-Fidâ Abdullah el-Kadî, Dâru'l-Kutubi'lilmiyye, 1. Baskı, Beyrut, 1987, c. X, s. 86, 190; Şihabuddin Ahmed b. Abdilvahhab en-Nuveyrî (ö. 733/1332), Nihâyetu'l-Ereb fi Fununi'l-Edeb, Nşr. Abdulmecid Tarhuyeynî, Dâru'l-Kutubi'l-
} 
onun hatırlı biri olmasından dolayı bazı zamanlar elçi olarak da görevlendirmiştir. ${ }^{15}$

1.2 Muhammed b. Bâhil b. Abdullah Ebû Muhammed Emir Şemsuddin elHakkârî: 620/1223 yılında dünyaya geldi. İskenderiye limanının komutanıydı. Edebiyata düşkün biriydi. Neseînin Sünen'inin tamamını ile Muhammed Kasım b. Ali el-Harirînin "el-Makamât" adlı kitabını el-Muvaffik Abdullatif b. Yusuf elBağdadîden Harran'da iken ders almıştı. Kendisinden, Harirînnin el-Makamâtını ders alan Üstad Ebu Hayyan Muhammed b. Ali b. Yusuf el-Endelusî, Kahire'ye geldiğinde bu kitabı onun rivayeti ile ders vermiştir. Muhammed b. Bâhil elHakkârî, meşhur hadis âlimi İmam Zehebîye birkaç kez icazet vermiştir. Kutbuddin Abdulkerim de kendisinden icazet alanlar arasındadır. Şiire ilgi duyan ibn Bâhil, İskenderiye'deki yöneticiliğinin yanında edebiyat ve gök bilimleriyle de ilgilenirdi. 683/1284 tarihinde ìskenderiye'de vefat etti. ${ }^{16}$

1.2. Ahmed b. Ebi Mansur b. Bâhil b. Abdullah el-Emir İmâduddin elHakkârî: Yukarıda zikrettiğimiz Muhammed b. Bâhil'in kardeşidir. İskenderiye'de saltanat naibi olarak yöneticilik görevini yürütüyordu. Allame Esiruddin Ebû Hayyân, onun için "dahi" sıfatını kullanmaktadır. illim ehline sonsuz bir sevgi ve muhabbeti vard. ${ }^{17}$ Kendisinin ne zaman vefat ettiğini bilmiyoruz.

1.4. Emir Bedruddin Ebû Abdullah Muhammed b. Muhammed Ebî Kasım el-Hakkârî: Haçlı Seferlerinde görev yapmış bir komutandır. el-Meliku'lMuazzam'ın komutanı ve müsteşarı idi, Sultan onun görüşlerine büyük bir önem verirdi. Dindar, fakirlere düşkün ve çokça sadaka veren biriydi. el-Halil kentinde de Yûnus (a.s.)'ın makamı yanında yolun ortasında bir cami yaptırmışırır. Daima şehit olmak için dua ederdi ve 614/1217 yılında Haçlı Seferleri esnasında şehit düştü ve Kudüs'e nakledildi. ${ }^{18}$ ibn Kesir, onun türbesinin hâlâ ziyaret edildiğini bildirmektedir. ${ }^{19}$

1.5. Seyfuddin Ebî Hasan Ali b. Ebi'l-Heycâ el-Hakkârî: Bir savaş esnasında yüzüne aldığı bir yaranın açtığı izden dolayı "Meştûb" (yarılmış) diye şöhret bulmuştur. Babası Ebu'l-Heycâ, Hakkâri'deki İmâdiyye Kalesi ile yakınındaki diğer

ilmiyye, I. Baskı, Beyrut, 2004, c. XXVIIl, s. 281; Hayruddin Ziriklî, el-A'lâm Kâmûsu Terâcim, Dâru'l-ilm li'l-Melâyîn, Beyrut, 1986, c. V, s. 107.

${ }^{15}$ Tacuddin es-Subkî, Tabakatu'ş-Şâfiîyyeti'l-Kübrâ, c. II, s. 353, 354.

${ }^{16}$ Selahuddin Halil b. Aybek es-Safedî (ö. 764/1363), el-Vâfí bi'l-Vefeyât, Nşr. Ahmed Arnaût ve Türki Mustafa, Daru ihyai't-Turasi'l-Arabî, I. Baskı, Beyrut, 2000, c. 11, s. 173, 174; Şemsuddin Ebû Abdullah Muhammed b. Ahmed b. Osmân b. Zehebî (ö. 748/1347), Târihu'l-íslâm ve Vefeyâtu'l-Meşahir ve'l-A'lâm, Nşr. Ömer Abdusselâm Tedmurî, Dâru'l-Kitabi'l-Arabî, ı. Baskı, Beyrut, 1993, c. Ll, s. 159, 160; Takiyyuddin Ebû Tayyib el-Mekkî, Zeylu't-Takyîd, c. 1, s. 111.

${ }^{17}$ Safedî, el-Vâfi bi'l-Vefeyât, c. VIII, s. 122.

${ }^{18}$ Safedî, el-Vâfi bi'l-Vefeyât, c. IV, s. 249; Ziriklî el-A'lâm, c. VII, s. 27.

${ }^{19}$ İmâduddin Ebu'l-Fida Hâfız ibn Kesir (ö. 774/1372), el-Bidâye ve'n-Nihâye, Nşr. Abdullah b. Abdilmuhsin et-Turkî, Dâru'l-Hicr, ı. Baskı, Beyrut, 1997, c. XVIl, 68. 
kalelerin hakimiydi. ${ }^{20}$ Seyfuddin Ebî Hasan el-Hakkârî, Haçlı Seferleri esnasında görev yapmış bir komutandır. Eseduddin Şirku ile birlikte Mısır'ın fethinde bulunmuştu. Zengi devletinin Mısır'daki komutanlarındandır. Ömrünün sonlarına doğru Selâhaddin Eyyûbî̀nin hizmetine girmiştir. Haçlı Seferleri esnasında esir düşünce elli bin dinar karşılı̆̆ında serbest bırakılmıştır. Eyyûbî Devletinde şan ve şöhrette kendisine yaklaşan kimse yoktu. Selâhaddin Eyyûbî, Nablus şehrinin tamamını ikta olarak kendisine vermişti. Safedî, önce Kudüs'ün daha sonra Nablus'un kendisine ikta olarak verildiğini ifade etmektedir. ${ }^{21}$ Kendisine "el-Emiru'lKebir” (büyük komutan) denilirdi. Akkâ'da Sultan'ın vekili olarak valilik görevini yürütürdü. Nablus'ta 588/1192 yılında esaretten kurtulduktan yüz gün sonra vefat etmiş ve evine defnedilmiştir. ${ }^{22}$

1.6. Emir İmâduddin Ebû Abbâs Ahmed b. el-Emiru'l-Kebir Seyfuddin Ebî Hasan Ali b. Ebi'l-Heycâ b. Abdullah b. Ebi Halil b. Murtan el-Hakkârî: Yukarıda zikrettiğimiz zatın oğludur. ibn Meştûb diye şöhret bulmuştu. Meştûb (yarılmış) babasının lakabıydı, zira onun yüzünde derin bir yarık izi vardı. Takriben 575/1179 yılında dünyaya geldi. Emir İmâduddin ibn Meştûb, çok büyük bir komutandı. íbnu'l-Esir, "bütün komutanlar ona boyun eğer ve itaat ederlerdi, özellikle de Kürtler" demektedir. ${ }^{23}$ Sultanların yanında büyük bir itibara sahipti, kendilerinden biri gibi muamele ederlerdi. Babasına verilen Nablus iktalığını babasının vefatından sonra devam ettirmiştir. Gelirin üçte birini Beytu'lMukaddes'in hizmetleri için Selâhaddin Eyyûbînnin emriyle ayrıldığından, geriye kalan geliri kendisine kalıyordu. ibn Hallikân, kendisini 617/1220 yılında Musul Valisi Bedruddin Lu'lu' Atabek'in (ö. 657/1259) oyuna getirip yakaladığını ve hapsettiğini söyler. Bedruddin Atabek, Seyfuddin el-Hakkârî́yi Muzafferuddin ibnu'l-Meliki'l-Ấdil'e gönderir, o da Seyfuddin el-Hakkârîyi kendisine yakın tuttu ve bir müddet sonra buradan ayrılmasına müsaade etti. Bu ayrılış ibn Meştûb elHakkârînnin aleyhine oldu, Meliku'l-Eşref, onu yakalayıp Harran kalesine gönderdi ve esir muamelesi yaptı. Ayaklarına ağır zincirler ve ellerini tahtalara bağladı. Başı, sakalları ve elbiseleri bitlerden görünmez oldu ve bu hal üzere vefat etti. ${ }^{24}$ Emir İmâduddin ibn Meştûb, 619/1222 yılında Harran'da vefat etmiş, kızı Onun için Re'su'l-Ayn'da bir türbe inşa etmiş ve cenazesini Harran'dan oraya nakletmiştir. ${ }^{25}$

1.7. Emir Şemsuddin Muhammed b. Emir Bedruddin Ebi Mefahir Bâhil b. Abdullah b. Ahmed el-Hakkârî: İskenderiye limanının sorumlusuydu yani komu-

${ }^{20}$ ibn Hallikân, Vefeyâtu'l-A'yân, c. 1, s. 181.

${ }^{21}$ Safedî, el-Vâfi bi'l-Vefeyât, c. XX, s. 120.

${ }^{22}$ Nuveyrî, Nihâyetu'l-Ereb, c. XXIX, s. 81; ibn Kesir, el-Bidâye ve'n-Nihâye, c. XVI, 648, 649; Ziriklî, el-A'lam, c. IV, s. 256.

${ }^{23}$ ibnu'l-Esir, el-Kâmil fít-Târih, c. X, s. 376.

${ }^{24}$ ibn Hallikân, Vefeyâtu'l-A'yân, c. 1, s. 180, 181.

${ }^{25}$ Nuveyrî, Nihâyetu'l-Ereb, c. XXIX, s. 80, 81. 
tanıydı. Burada 683/1285 yılında vefat etti. İskenderiye Kalesi'nin Babû Reşîd denilen kapısının dış tarafında bulunan ve kendisinin yaptırdı̆̆ı ribata defnedil$\mathrm{di}^{26}$

1.8. Ebû Muhammed Şerefuddin ìsâ b. Muhammed b. Ebî Kasım elHakkârî: 593/1197 yılında Kudüs'te dünyaya geldi. Kendisi Baybars döneminde komutan ve devletin ileri gelenlerinden biriydi. Baybars, pek çok savaşta onu komutan olarak görevlendirmiştir. ilim ve edebiyatta uzman ve aynı zamanda şair biriydi. Şam'da 669/1270 yılında vefat etti. ${ }^{27}$

1.9. Dâvud b. Muhammed b. Ebî Kasım: el-Emiru'r-Reis İmâduddin Bedruddin el-Hakkârî: 690/1291 yılında Kudüs'te dünyaya geldi. Halep şehrinde ibnu'l-Letî, Hamid b. Ebi Umeyd el-Kazvinî, Zekî el-Birzalî, ibn Revaha, ibn Halil, ibn Kumeyre'den dersler aldı. Şam'da Tâc b. Ebî Ca'fer'den, Harran'da Ammar b. Muni', Mısır'da ise Abdulganî b. Benin'den hadis okudu. Nasıriyye Devleti zamanında Ca'ber kalesinin komutanlığı kendisine verildi. Şam ve Kudüs'te hadis dersleri verdi. $700 / 1300$ yılında vefat etti. ${ }^{28}$

1.10. Muhammed b. Dâvud b. Muhammed b. Ebî Kasım el-Emiru'r-Reis Bedruddin, İmâduddin el-Hakkârî: Yukarıda ismini zikrettiğimiz Dâvud b. Muhammed'in oğludur. 637/1239 yılında doğdu. O da, babası gibi muhteşem bir komutandı. ibn Revâha ve Yahya b. Kumeyr'den hadis derslerini aldı. Kendisi de bir müddet sonra hadis dersleri vermeye başladı. Kudüs'te 690/ı291 yılının Şaban ayında vefat etti. Babası, oğlunun ölümüyle âdeta perişan oldu. ${ }^{29}$

1.11. İzzuddin Ömer b. Ali el-Hakkârî: Bu zat ile ilgili bilgiyi bize yalnızca ibnu'l-Esir vermektedir. Ibnu'l-Esir, onun Halep'te bulunan komutanlardan biri ve Hakkârili Kürtlerden, güzel ahlâklı, çok güzel sıfatlara sahip cesur biri olduğunu bildirmektedir. ${ }^{30}$

1.12. İbn Mucelî Ali b. Ömer b. Mucellî Emir Nuruddin el-Hakkârî: Babası İzuddin büyük komutanlardan ve eski Halep valisiydi. Kendisi de Sultan'a vekâleten 659/1261 yılından 678/1279 yılına yaklaşık yirmi yıla kadar Halep valiliği görevini yürüttü. Emir Alâuddin Aydoğdu tarafından, ölümünden kısa bir süre önce bu görevinden alınmıştır. Güzel ve mütevazı bir yaşamı, tatlı dili, ilim ehline ve fakirlere yakınlığı vardı. Ölünceye kadar Halep'te kaldı. 678/1279 yılının Rebiulevvel ayının yirmi yedisi Çarşamba günü vefat etti. ${ }^{31}$

\footnotetext{
${ }^{26}$ Nuveyrî, Nihâyetu'l-Ereb, c. XXXI, s. 83.

${ }^{27}$ Ziriklî, el-A'lâm, c. V, s. 108.

${ }^{28}$ Selahuddin Halil b. Aybek es-Safedî (ö. 764/1363), A'yânu'l-Asr ve A'vânu'n-Nasr, nşr. Ali Ebu Zeyd ve diğerleri, Dâru'l-Fikr, ı. Baskı, Dımaşk, 1998, c. Il, s. 348, 349; Safedî, el-Vâfi bi'lVefeyât, c. 13, s. 312; Zehebî, Târihu'l-ìslâm, c. Lll, s. 475, 476.

${ }^{29}$ Zehebî, Târihu'l-islâm, c. Ll, s. 434, 435.

${ }^{30}$ ibnu'l-Esir, el-Kâmil fít-Târih, c. X, s. 487.

${ }^{3 l}$ Safedî, el-Vâfi bi'l-Vefeyât, c. XXI, s. 243; Zehebî, Târihu'l-islâm, c. L, s. 307, 308.
} 
1.13. İsâ b. Muhammed b. Ebî Kasım b. Muhammed b. Ahmed Emir Şerefuddin Ebû Muhammed b. Emir Abdullah el-Hakkârî el-Kürdî: 593/1197 yılında dünyaya geldi. Kudüs'te Abduhakk'ın "el-Ahkam" adlı eserini ders aldı. Ebû Hasan Ali b. Muhammed b. Cemil el-Me'afirî́den de "el-Musannef 1 okudu. Ömer b. Taberzad'dan ve başkalarından icazet aldı. Şeyh Burhanuddin el-i̇skendereyanî ve Kadı'l-Kudât ibn Cema'a da kendisinden el-Ahkâm'ı ders aldılar. Cesaretiyle meşhur bir komutandı, Haçlı Seferlerinde dillerden düşmeyecek kahramanlıklarda bulundu. 669/1270 yilinda vefat etti. ${ }^{32}$

1.14. Ömer b. Muzaffer Emir Cemaluddin el-Hakkârî: Şam'da hem ilim halkasının hem de komutanların önde gelenlerindendi, iyiliksever ve muhtaç insanların ihtiyacını gideren biriydi. Çok cesur bir komutan ve dini bütün biriydi. 680/1281 yılında Humus yakınlarındaki Massaf savaşında elli yaşını aşkınken Moğollar tarafindan şehit edilmiştir. ${ }^{33}$

1.15. İsâ el-Kürdî el-Hakkârî: Halep şehrinin kale surlarının dış tarafında Bankusa denilen yerde kendi adıyla anılan bir camisi vardır. Halep'te polis teşkilâtının şefi olarak görev aldığının dışında kendisi hakkında her hangi bir bilgiye sahip değiliz. ${ }^{34}$

\section{Hakkârili Kadılar (Hâkimler)}

Bilindiği gibi eskiden bugünkü hâkimlik mesleğine denk gelen kadılık görevi mevcuttu. Kadılar bulundukları bölgenin en üst düzey hâkimleriydi. Bazen bir şehirde semtlere bağlı olarak veya her mezhebe özel olmak şartıyla birden fazla kadı bulunabilirdi. Bu durumda bütün bu kadılarla birlikte ülkedeki kadıların bağlı oldukları Kadı́l-Kudât (başkadı) makamı da mevcuttu. Burada bu tür görevlerde bulunmuş Hakkârili âlimleri tanıtacağız.

2.l. İmâduddin Abdulaziz b. Ahmed b. Osmân b. İsâ b. Ömer b. Hıdır elHakkârî b. Hatib el-Eşmûnîn Ebu i $\mathbf{z z}$ b. Takiyyuddin: Kendisi daha çok "ibn Hatib el-Eşmûnîn" olarak bilinirdi. Kahire'de kadılık görevinde bulunmuştur. ${ }^{35}$ ibn Hatib el-Eşmûnîn, Kahire'de bir mahallenin kadılığına bakıyordu. ${ }^{36}$ Kahire'nin batı yakasındaki Selâm Mahallesi'nin işlerinden sorumluydu ve Kadı'l-Kudât

${ }^{32}$ Zehebî, Târihu'l-ìslâm, c.XL, s. 292, 293.

${ }^{33}$ Zehebî, Târihu'l-İslâm, c. L, s. 361.

${ }^{34}$ ibn Şeddâd, İzzuddin Muhammed b. Ali b. ibrahim, A'laku'l-Hatire fi Zikri'l-Ulemâi'ş-Şam ve'lCezîre, nșr. Yahya Zekeriya Abbare, el-Vezâretu's-Sakafiyye, Dımaşk, 1991, c. 1, s. 121.

${ }^{35}$ Hâfız Şemsuddin Muhammed b. Abdurrahman es-Sehavî (ö. 902/1496), el-Buldaniyât, nşr. Hassan b. Muhammed el-Kattan, Dâru'l-Atâ, Suudi Arabistan, 2001, s. 254

${ }^{36}$ Tacuddin es-Subkî, Tabakatu'ş-Şâfiîyye, c. X, s. 82; ibn Kesir, el-Bidâye ve'n-Nihâye, c. XVIII, s. 285 . 
Celâluddin adına bu işleri yürütürdü. ${ }^{37}$ Mekke'de Abdussamed ibn Asâkir'den hadis dersleri aldı ve Onun "Buldaniyât" adlı kitabını da okudu. Şam'a 705/1305 yılında geldi ve pek çok âlimden ders aldıktan sonra ilimde önde gelenlerden biri oldu. Fıkıh ve kanun konusunda iyi bir uzmandı ve aynı zamanda kelâm ilimleri alanında da bilgindi. ibn Mısrîden (ibn Sasrâ) sonra Şam kadılı̆̆ına tayin edildi. ${ }^{38}$ Safedî, buradaki kadının lojmanı büyük bir saray olduğundan mütevazı bir hayat yaşayan ibn Hatib el-Eşmûnîn'in bunu kabul etmediğini ve kendisinden bin kadar hikmetin istinbat edildiğini kaydetmektedir. ${ }^{39} \mathrm{ibn}$ Arabînnin hadisleri üzerine "el-Mecâmi" fi Nehâri Ramazân" adlı Şeyh İmam Valid'in talikindeki hadise bir şerh ve daha pek çok güzel eser kaleme almıştır. 727/1327 yılında Kahire'de vefat etmiştir. ${ }^{40}$

2.2. Muhammed b. Abdullah b. Ahmed Kadı Bedruddin Ebû Abdullah elHakkârî es-Sılatî: Takriben 630/1233 yılında dünyaya geldi. Humus kadılığı yapmıştır. Babası Ürdün'ün doğusundaki Salt kasabasında müderris idi, o da babasıyla birlikte ilimle meşgul olurdu, dolayısıyla burada büyüdü. Daha sonra yine babasıly birlikte Kudüs'e gittiler ve burada ilimle meşgul oldular. Kudüs'te babasının vefatından sonra müderris olarak görev almıştır. Daha sonra Şam'a geçmiş ve buradaki âlimlerden hadis dersleri almıştır. 660/1262 yılında Mısır'a gelerek buradaki hocalardan da hadis dersleri aldı. Akabinde Salt'ta müderris olarak öğretimde bulunmasının yanında Salt’ın kadılı̆ına atanmıştır. Bilâhare önce Humus daha sonra Kudüs kadılıklarında da bulunmuştur. Bütün bunlara ilâveten Bulkînî, onu Hisbân'ın kadılığına atadı. Buralardaki üstün başarılardan sonra Halil ve Nablus'ta da kadı olarak görev aldı. Birçok yerde kadılık yaptıktan sonra en son Humus kadılı̆̆ına geri döndü. Muhammed b. Halef el-i̇zzînin “Meydanu’lFursan" adlı kitabını "ihtisâru Meydâni'l-Fursân" adıyla üç ciltlik bir ihtiłsâr hâlinde keleme aldı. Çok sayıda kitabın özetini ihtiva eden bu eser, âlimler tarafından çok farklı ve faydalı görülmüştür. ${ }^{41}$ ibn Teymiyye'nin 6 ciltlik “Der'u Te'ârudi'l-Akl ve'n-Nakl' adlı kitabını iki cilt hâlinde kısaltan bir muhtasar yazmıştır. Muhammed b. Abdullah el-Hakkârî, eserinde, Şeyh İzzuddin'den söz

\footnotetext{
${ }^{37}$ Nuveyrî, Nihâyetu'l-Ereb, c. XXXIII, s. 186.

${ }^{38}$ Ebû Bekr b. Ahmed b. Muhammed b. Ömer ibn Kadı Şuhbe (ö. 851/1448), Tabakatu'ş-Şâfiîyye, nşr. Hâfız Abdulalim Han, Dairetu'l-Me'arifi'l-Osmâniyye, 1. Baskı, Hind, 1979, c. Il, s. 346; ibn Hacer el-Askalanî, Şihabuddin Ahmed b. Ali (ö. 852/1448), ed-Dürerü'l-Kâmine fi A'yâni'lMieti's-Samine, Dâru'l-Cîl, Beyrut, 1993, c. Il, s. 368, 369; ibn Kesir ed-Dımaşkî, Tabakatu'lFukahâi'ş-Şâfiîyye, c. III, s. 181.

${ }^{39}$ Safedî, A'yânu'l-Asr, c. III, s. 67.

${ }^{40}$ Tacuddin es-Subkî, Tabakatu'ş-Şâfiîyye, c. X, s. 82; Safedî, el-Vâfi bi'l-Vefeyât, c. XVIII, s. 284; ibnu'l-ìmâd Şihabuddin Ebu Ferec Abdulhayy b. Ahmed b. Muhammed el-Akrî ed-Dımaşkî (ö. 1089/1676), Şezerâtu'z-Zeheb fi Ahbari Men Zeheb, nşr. Abdulkadir el-Arnaût, Mahmud elArnaût, Daru ibn Kesir, 1. Baskı, Beyrut, 1986, c. VIIl, s. 138.

${ }^{41}$ ibn Kadı Şuhbe, Tabakatu'ş-Şâfiîyye, c. III, s. 224, 225.
} 
ederken, onun bir defasında yanlış fetva verdiğini ve sonra verdiği bu fetvanın yanlış olduğunu anlayınca, Kahire ve Mısır'da kendisini kastederek "filan kişi şöyle bir fetva vermiştir, onunla amel edilmez, o yanlış bir fetvadır" diye bağırarak ilân ettiğini kaydeder. 786/1384 yılında vefat etmiştir. ${ }^{42}$

2.3. Süleyman b. Yusuf b. Ebi Adl Fahruddin el-Hakkârî: Takriben 680/1281 yılında dünyaya geldi. Mısır mahkemelerinde hâkim olarak görev yapıyordu. Kendisi ve oğlu Muvaffikuddin ile birlikte Sibtu's-Silefĩ den ders aldılar. 695/1296 yılının Safer ayında vefat etti. ${ }^{43}$

2.4. Ahmed b. Osmân b. İsâ b. Ömer b. Hıdır el-Hakkârî: 632/1234 tarihinde dünyaya geldi. Eşmus'ta hatip idi ve daha sonra buranın kadısı oldu. Esyut'un dışında başka yerlerde de kadılık yaptı. Babası Necmuddin b. Zeynuddin de kendisinden önce Eşmus kadısı idi. Sibt ve Munzirî gibi âlimlerden ders aldı. Bu zat meşhur Kadı'l-Kudât Reis i̇zzuddin Ebu'l-Fadl Abdulaziz'in babasıdır, İmâduddin ise bu zatın kardeşidir. 695/1296 yılının Rebiulevvel ayının dokuzunda vefat etti. ${ }^{44}$

\section{3-Hakkârili Âlimler}

Aslen Hakkârili olup da i̇slâm dünyasının çeşitli şehirlerinde ilim tahsil edip tabakat kitaplarında yer alacak kadar şöhrete kavuşmuş âlimlerden tespit edebildiklerimizi burada tanıtmaya çalışacağız.

3.1. Şihabuddin Ebû Hasan Ahmed b. Ahmed b. Hüseyin b. Mûsek elHakkârî:: $674 / 1275$ yılında doğdu. Hadis ilmiyle meşgul oldu, ilmi ilk olarak edDimyatîden aldı. İskenderiye'ye giderek orada da ilim tahsil etti. Kur'ân'ın beş kıraatini Şeyh İzzuddin el-Emyûtîden ders aldı, bu zattan aynı zamanda fikıh dersleri de aldı ve Tenbih adlı kitabı huzurunda okuyup bitirdi. Yedi kıraati Şeyh Nuruddin eş-Şetnufî ve Kadı Meciduddin b. Haşşab eş-Şafiî den ders aldı. Allame Bahauddin b. Nahhas el-Halebî̀den Şatibiyye ve Ratibiyye kitaplarını okudu, ibn Mâlik'in Elfiyyésini de bu zata arz etti. Mansuriye Medresesi'nde hem Kur'ân kürsüsünde hem de hadis kürsüsünde müderris oldu. ${ }^{46}$ Aynı zamanda Hâkim Camiinde de hadis okuturdu. Güzel el yazısıyla pek çok kitabı çoğaltmak için

${ }^{42}$ Tacuddin es-Subkî, Tabakatu'ş-Şâfiîyye, c. VIIl, s. 214; ibn Hacer el-Askalanî, ed-Dürerü'lKâmine, c. III, s. 466; ibn Hacer el-Askalanî, Şihabuddin Ahmed b. Ali (ö. 852/1448), Inbâu'lĞumr bi Enbâi'l-Umr, nşr. Muhammed Tevfik Uveyde, ihyau't-Turasi'l-ìslâmî, Kahire, 1969, c. I, s. 297; ibnu'l-ìmâd, Şezerâtu'z-Zeheb, c. VIIl, s. 503; Ziriklî, el-A'lâm, c. Vl, s. 236.

${ }^{43}$ Zehebî, Târihu'l-ìslâm, c. Lll, s. 255, 256.

${ }^{44}$ ibn Kesir ed-Dımaşkî, Tabakatu'l-Fukahâi'ş-Şâfiîyye, c. III, s. 99, 100.

${ }^{45}$ Ebu Nu'aym Ahmed b. Abdullah b. Ahmed b. İshak el-ìsbehânî, el-Musnedu'l-Mustahrec alâ Sahihi Imam Müslim, nşr. Muhammed Hasan İsmail eş-Şâfî̂, Dâru'l-Kutubi'l-ilmiyye, ı. Baskı, Beyrut, 1996, c. 1, s. 258.

${ }^{46}$ Şemsuddin Ebu'l-Hayr Muhammed b. Muhammed b. Ali ibni'l-Cezerî (ö. 833/1430), Gayetu'nNihâye fi Tabakati'l-Kurrâ, Dâru'l-Kutubi'l-ilmiyye, 1. Baskı, Beyrut, 2006, c. 1, s. 39. 
yazdı, Kütüb-i Sitte de bu şekilde çoğalttığı kitaplardan biriydi. Muhammed b. ỉbrahim el-Mazinîden Tirmizînin el-Câmi' adlı hadis külliyatının yarısını ders aldı ve daha sonra rivayette bulundu. Diğer yarısını ise kendisinden dinlemeden icazet yoluyla rivayet etti. Kendisinden pek çok kişi ders almıştır. Mekke'de 749/1348 yılında çok kişiye ders verdi. 750/1349 yılının Cumâde'l-ûla ayında da vefat etti. ${ }^{47}$

3.2. Şeyh Şihabuddin Ebu Said Ahmed b. Ahmed b. Ahmed b. Hüseyin b. Mûsek el-Hakkârî: Yukarıda zikrettiğimiz Şihabuddin Ebû Hasan el-Hakkârînin oğludur. Babası ile birlikte Muhammed b. Ali b. Said, el-Mevsimî ve Sittu'lVüzera kendisinden ders almışlardır. Kendisi de ibn Sevvaftan Neseînin Sünen'ini, Ebû Hasan b. Kayyim ve başkalarından ders aldı. Hâkim Camiinde muid (müderris yardımcısı) olarak görev aldı. Bu zat aynı zamanda Hakkârili meşhur Cüveyriyye adlı kadın âlimin babasıdır. Kızı kendisinden ders almıştı. 763/1362 yılının Cumâde'l-Uhrâ ayında vefat etti. ${ }^{48}$ Mısır'da yetişmiş çok iyi bir müfessir ve hadis ricalini bilen Kürt asıllı bir alimdi. Kahire'de Mansuriyye Medresesi'nde Kur'ân kürsüsünde müderristi. Kadı'l-Kudât Muvaffikuddin el-Hanbelî, Onun görev alması için aynı medresedeki hadis kürsüsünü kendi isteğiyle terk etti. ${ }^{49}$ Bunun üzerine bu medresede hadis derslerini de vermeye başladı. Kendisinin çokça kaynak gösterilen 6 ciltlik "Tefsiru'l-Hakkâri" diye bilinen ve kendisinin "Tefsiru'l-Kur'ân" ismini verdiği bir tefsiri vardır. Ahmed b. Musa el-Hakkârînin aynı zamanda, "Ricalu'l-Buharî ve Müslim" adlı bir kitap yazmıştır. ${ }^{50} \mathrm{Bu}$ zatın, aynı zamanda "Ricalu's-Süneni'l-Erba'a" adlı bir kitabı daha vardır. ${ }^{51}$ Şeyh Şihabuddin el-Hakkârîn nin matematik ve geometri alanında da "Kitabu'l-Mesaha” adlı bir eseri vardır. 763/1362 yılında vefat etmiştir.

3.3. İmâduddin Muhammed b. Ahmed b. Osmân el-Hakkârî: Muhammed b. Ebu'ş-Şerifî el-Hâlikîye Bâbu's-Sucud'dan ders verdi. ${ }^{52}$ Bilbis Kadısı İzzuddin'in

47 ibn Hacer el-Askalanî, ed-Dürerü'l-Kâmine, c. 1, s. 99; Muhammed b. Ahmed b. Ali Takiyyuddin Ebû Tayyib el-Mekkî el-Fasî (ö. 832/1429), Zeylu't-Takyîd fî Ruvâti's-Sünen ve'l-Esânid, nşr. Kemal Yûsuf Hût, Dâru'l-Kutubi'l-ilmiyye, I. Baskı, Beyrut, 1990, c. l, s. 287; ibn Rafi', Takiyuddin Ebu'l-Me'alî Muhammed b. Rafi' es-Selamî (ö. 774/1372), el-Vefeyât, nşr. Sâlih Mehdi Abbâs ve Beşşâr Avvar Ma'ruf, Müessesetu'r-Risâle, 1. Baskı, Beyrut, 1982, c. 11, s. 122-124.

${ }^{48}$ ibn Hacer el-Askalanî, ed-Dürerü'l-Kâmine, c. 1, s. 98; Celâluddin Abdurrahman b. Ebi Bekr esSuyutî (ö. 911/1505), Hüsnüll-Muhadara fi Târihi Misr ve Kahire, nşr. Muhammed Ebu'l-Fadl ibrahim, Daru ihyai'l-Kutubi'l-Arabiyye, 1. Baskı, Kahire, 1967, c. 1, s. 380, 381.

${ }^{49}$ Safedî, $A^{\prime} y^{\prime}{ }^{5} u^{\prime} l-A s r$, c. l, s. 169.

${ }^{50}$ Ebû Bekr Kâfî, Menhecu'l-imami'l-Buharî fî Tashihi'l-Ehadis ve Ta'lilihâ, İşraf: Hamza Abdullah el-Melyubarî, Daru ibn Hazm, 1. Baskı, Beyrut, 2000, s. 62.

${ }^{51}$ Ebû Abdullah Muhammed b. Ca'fer el-Kettanî, er-Risâletu'l-Mustatrefe li Beyani Meşhuri Kutubi's-Sünneti'l-Musannefe, nşr. Muhammed el-Muntasır Muhammed ez-Zemzemi el-Kettanî, Dâru'l-Beşairi'l-i̇slâmiyye, Beyrut, 1986, s. 206; Ziriklî, el-A'lâm, c. l, s. 91.

${ }^{52}$ Ebu Nu'aym el-i̇sbehânî, el-Musnedu'l-Mustahrec, c. Il, s. 223. 
kardeşidir. Hâfiz Ebu Ahmed ed-Dimyatînnin talebesidir ve O'ndan hadis dersleri almıştır. Eşmûnîn'de 708/1308 yılında vefat etti. ${ }^{53}$

3.4. Ömer b. Muhammed b. İsâ Ebû Hafs Muciduddin el-Kürdî el-Hakkârî: Yukarıda ismini zikrettiğimiz ìsâ b. Muhammed'in bir diğer kardeşidir. 560/1165 yılında dünyaya geldi. Mısır'da Asâkir b. Ali'den ve ískenderiye'de ise ibn Muvakka'dan ders aldı. Ayrıca Silefĩden de hadis derslerini okudu. Zeki el-Munzirî ve Mısırlı pek çok âlim de kendisinden ders almışlardır. Muhammed b. Muşrik elHaşşâb da kendisinden icazet almıştır. Daha çok Fakih i̇sâ el-Hakkârînin kardeşi olarak tanınırdı. Eyyûbî Devletinin nezdinde büyük bir itibarı vardı. 636/1238 tarihinde vefat etmiştir.

3.5. Hâcib Halil el-Hakkârî: Bu zat 585/1189 yılındaki Haçlı Seferleri esnasında öldürülenlerdendir. ${ }^{54}$ Bunun dışında kendisi ile ilgili herhangi bir bilgiye ulaşamadık.

3.6. Ebû Abbâs Ahmed b. Ebî Bekr b. Abdussamed b. Mercan el-Hakkârî el-Gasulî: Genellikle "ibn Mercan es-Sâlihî" olarak tanınırdı. 660/1262 yılından önce doğduğu tahmin edilmektedir. Fahr b. Buharîden Ibn Zahirî ve Ahmed b. Daim yoluyla gelen rivayetlerle Sahih-i Müslimi ders aldı ve bir müddet sonra kendisi de Sahih-i Müslim'den ders verdi. İbn Rafi' ve Birzalî kendisinden ders alan öğrencilerindendir. 735/1334 yılının Safer ayında vefat etmiştir. ${ }^{55}$

3.7. Ahmed b. Abdurrahman b. ibrahim b. Ali b. Ahmed b. ibrahim elHakkârî es-Serhadî et-Turî el-Mukaddesî: Ebû Abbâs ibn Şuca' olarak da bilinirdi. 646/1248 yılında Sâlihiyye'de doğdu. Hatib Merdan, ibn Abduddaim ve başkalarından ders aldı. Çok az gülen, dini güzel yaşayan bir zattı. Kendisi Kur'ân Hâfızı idi ve çok güzel Kur'ân okurdu. 736/1335 yılının Rebi'u'l-Evvel ayında doksan yaşında vefat etti. ${ }^{56}$

3.8. Ahmed b. Ali b. Hasan b. Dâvud el-Cezerî el-Hamevî Şihabuddin elKurdî Ebû Abbâs el-Hakkârî: 649/1251 yılında dünyaya geldi. Muhammed b. Abdulhadi ve kardeşi Abdulhumeyd, ibn Hacer el-Askalanînin babası, ibn Abduddâim, el-Yeldanî, Abdulvahhab ibn Nasih ve başkalarından dersler aldı. Muhammed b. İsmail el-Mukaddesî ve Hatib Merdan'dan ibn ìshak'ın "es-Siretu'nNebeviyye" adlı kitabı ile ibn Hişâm'ın "et-Tehzib”ini ömrünün son beş yılında ders aldığında, elli üç yaşındaydı. Kendisine el-Mübarek el-Havvas, Fadlullah elCîlî, Yusuf Sibt ibnu'l-Cevzî ve başkaları icazet verdi. Önce Hama'da ve daha

53 ibn Hacer el-Askalanî, ed-Dürerü'l-Kâmine, c. III, s. 338.

${ }^{54}$ Nuveyrî, Nihâyetu'l-Ereb, c. XXVIII, s. 281.

${ }^{55}$ Takiyyuddin Ebû Tayyib el-Mekkî, Zeylu't-Takyîd, c. l, s. 302.

${ }^{56}$ ibn Hacer el-Askalanî, ed-Dürerü'l-Kâmine, c. 1, s. 165; ibnu'l-İmâd, Şezerâtu'z-Zeheb, c. VIII, s. 196; es-Safedî, $A^{\prime}$ yânu'l-Asr; c. l, s. 257, 258; Şemsuddin Ebû Abdullah Muhammed b. Ahmed b. Osmân b. Zehebî (ö. 748/1347), el-iber fi Haberi Men Ğaber, nşr. Ebu Hacer Muhammed esSaid b. Besyunî Zağlul, Dâru'l-Kutubi'l-ilmiyye, 1. Baskı, Beyrut, 1985, c. IV, s. 104; Takiyyuddin Ebû Tayyib el-Mekkî, Zeylu't-Takyîd, c. I, s. 328; Safedî, el-Vâfi bi'l-Vefeyât, c. VIl, s. 31. 
sonra Şam'da ikamet etti ve hadis dersleri verdi. ilmiyle dönemin önde gelen âlimlerinden olduğundan her taraftan kendisine öğrenci gelirdi. Zehebî ve Subkî, onu ilmi ve dini yaşayış yönüyle methederler. 743/1342 yılının Şaban ayının beşinde doksan dört yaşında vefat etti. ${ }^{57}$

3.9. Ebû Abbâs Ahmed b. Muhammed b. Ebìz-Zuhr b. Sâlim el-Gasulî elHakkârî: 680/1281 yılında dünyaya geldi. Fahr b. Buharî den Ahmed b. Hanbel'in “Müsned'ini ve başka dersler aldı. Başka hocalardan da ders aldı. Kendisi de bir müddet sonra hadis derslerini vermeye başladı. Meşhur i̇slâm âlimlerinden Zehebî, el-lrakî, ibn Receb ve et-Tenuhî kendisinden ders alan talebelerindendir. 760/1359 yılının Cumâde'l-ûlâ ayında Şam'da vefat etti ve Sefhu'l-Kasiyun denilen yerdeki mezarlığa defnedildi. ${ }^{58}$

3.10. Abdullah b. Hasan b. Muhammed b. Abdullah el-Ğammarî el-Hakkârî: 547/1152 yılında Hakkârî yakınlarındaki İmâdiye Kalesinde dünyaya geldi. Ebu'lVakt Abdulevvel b. ìsâ b. Şuayb es-Secezĩden umumi icazetle ile Şerefuddin edDimyatî́den de Sahih-i Buharîyi ders aldı. Ebu Ali Hanbel b. Abdullah elBağdadîden de Ahmed b. Hanbel'in “Müsned'inin tamamını ders aldı. Yüz beş yaşında Halep'te 652/1254 yılında vefat etti. ${ }^{59}$

3.11. Ali b. Ahmed Şeyhu'l-i̇slâm Ebû Hasan el-Hakkârî: 490/1097 yilında doğdu. Ebu Süfyan'ın oğlu Utbe'nin soyundandır. Genellikle "Şeyhu'l-ìslâm elHakkârî" olarak anılırdı. Hadis almak için pek çok şehir gezdi ve oralardaki âlimlerden ders aldı. Abdullah b. Nazif el-Ferrâ'dan hadis rivayet ederdi. Ebû Kasım ibn Asâkir, onun mevsuk (rivayet açısından güvenilir) olmadığını söylerdi. ibn Neccâr da, onun hadis uydurduğunu söylemiştir. Şeyhu'l-i̇slâm el-Hakkârî, Musul'da Ca'fer b. Muhtar'dan, Seyda'da Ebû Hasan b. Cemi'den, Mısır'da Ebû Abdullah ibn Nazif el-Ferrâ'dan, Mekke'de ibn Sahr'dan, Bağdat'ta Ebû Kasım ibn Bişran'dan hadis derslerini almıştı. Hadislerinin pek çoğu, "münker" ve "acaib" hadislerden oluşurdu. íbnu'l-Esir de, "hadislerinde sebebi bilinmeyen çok acayip şeyler vardı" demektedir. ${ }^{60}$ Çok ibadete düşkündü, bu yüzden genellikle dağlarda yalnız başına ibadet etmeyi severdi. Mutasavvıflara ait ribatlara ve fakirlerin takıldığı mekânlara da devam ederdi. Bu yüzden kendisine "Şeyhu'l-i̇slâm" lakabı takılmıştı. Âlimler, "sen Şeyhu'l-i̇slâmsın" dediklerinde, "ben i̇slâm'da bir şeyhim (ihtiyar)" diye cevap vermişti. 486/1093 yılının Muharrem ayının başlarında vefat

57 ibn Hacer el-Askalanî, ed-Dürerü'l-Kâmine, c. l, s. 207, 208; Takiyyuddin Ebû Tayyib el-Mekkî, Zeylu't-Takyîd, c. l, s. 344.

58 ibn Hacer el-Askalanî, ed-Dürerü'l-Kâmine, c. I, s. 263; ibnu'l-İmâd, Şezerâtu'z-Zeheb, c. VIII, s. 324; Takiyyuddin Ebû Tayyib el-Mekkî, Zeylu't-Takyîd, c. l, s. 393.

${ }^{59}$ Zehebî, Târihu'l-islâm, c. XLVIII, s. 124, 125; Takiyyuddin Ebû Tayyib el-Mekkî, Zeylu't-Takyîd, c. Il, s. 32 .

${ }^{60}$ ibnu'l-Esir, el-Kâmil fït-Târih, c. VIII, s. 491; Zehebî, el-iber, 1985, c. Il, s. 352. 
etmiştir. ${ }^{61}$ Şeyhu'l-i̇slâm el-Hakkârî, “i'tikadu'l-imami’ş-Şafiì adlı bir eser kaleme almıştır. ${ }^{62}$

3.12. ìsâ b. Musa b. Ebî Bekr b. Hıdır b. ỉbrahim el-Hakkârî: Yukarıda ismini verdiğimiz Şeyhu'l-i̇slâm Ali b. Ahmed'in kardeşidir. Daha çok ibn Şeyhu'lİslâm diye tanınırdı. İyi yetişmiş bir fakih, zahit bir insan, cesur bir askerdi. Bir müddet Caruhiye Medresesi'nde ders vermiş ve daha sonra Mısır'a geçmiş ve 658/1260 yilında Mısır'da vefat etmiştir. ${ }^{63}$

3.13. Şeyh Tâhâ b. Molla Ahmed b. Sâlih en-Nehrî el-Hakkârî el-Geylanî: Hz. Ali'nin (k.v.) oğlu Hasan (r.a.) sülalesindendi. Aynı zamanda Abdulkadir Geylanînin de soyundandır. Bu aile göç edip Hakkâri mıntıkasına gelmiş ve Kürtleşmiştir. Seyyid Tâhâ ile Amcası Abdullah, Mevlâna Hâlid Bağdadînnin halifeleriydiler, fakat Seyyid Tâhâ halkın gözündeki heybetinden dolayı şöhrette amcasını gölgede bırakmıştır. Bu bölgedeki bütün Kürt aşiretleri kendisine büyük bir saygı gösterirlerdi. Osmânlı Sultanlarının yanında da bölgedeki siyasî nüfuzu sebebiyle büyük bir itibarı vardı. Kendisinden dolayı, halifeleri de büyük bir şöhrete sahip idiler. Nakşibendî tarikatının öğretilmesinde ve yayılmasında Arvasî ve Küfrevî ailelerinin kendisine tabi olmalarından dolayı önemli bir hizmeti olmuştur. ${ }^{64}$

3.14. Şerefuddin Ebu Fedail Adî b. Musâfir b. İsmail el-Hakkârî: Mervan b. Hakem'in soyundandır. Bağlılarına kendi isminden dolayı "Adeviyye" tarikatının mensupları denirdi. Ba'lebek'e bağlı Beytu'l-Karr'da doğdu, (ibn Kesir Şam'ın batı taraflarında Beytu'l-Farr köyünde olduğunu söyler) ${ }^{65}$ ibn Hallikân, doğduğu köyün kendisine atfedilen kutsiyetten dolayı "günümüze kadar ziyaret edilmektedir" demektedir. Bağdat'a geldiğinde burada Şeyh Abdulkadir, Şeyh Debbas, Şeyh Ukayl el-Mencibî, Ebi'l-Vefa el-Hulvanî, Ebu Necib es-Sühreverdî ve başka hocalardan ders alır. Yaklaşık dört yıl Medine'de kaldı ve daha sonra Hakkâri'ye gelerek burada bir zaviye inşa etti. Bu zaviye, tasavvufi öğretimle birlikte adeta bir medrese gibi de öğretim vermiştir. Kendisi ile ilgili bilgiler, "Behcetu Sultani'lEvliyâi'l-Ârifin" içinde "Fîll-Hurkati'n-Nebeviyye ve Fedaili'ş-Şeyh Adî" de bir araya

${ }^{61}$ Ahmed b. Ali ibn Hacer el-Askalanî (ö. 852/1448), Lisânu'l-Mizan, nşr. Abdulfettah Ebû Ğudde, Mektebu Matbuati'l-i̇slâmiyye, 1. Baskı, Beyrut, 2002, c. V, s. 483, 484; ibnu'l-ìmâd, Şezerâtu'zZeheb, c. V, s. 370; ibn Hallikân, Vefeyâtu'l-A'yân, c. III, s. 345; ibn Tağriberdî, Cemaluddin Ebu Mehasin Yûsuf b. Tağriberdî,el-Atabekî (ö. 874/1469), en-Nucumu'z-Zahire fî Mulûki Mısr ve'l-Kahire, nşr. Muhammed Hüseyin Şemsuddin, Dâru'l-Kutubi'l-ilmiyye, Beyrut, ts., c. V, s. 136; Safedî, el-Vâfí bi'l-Vefeyât, c. XX, s. 120.

${ }^{62}$ Ebû Abdullah Muhammed b. Ca'fer el-Kettanî, er-Risâletu'l-Mustatrefe li Beyani Meşhûri Kutubi's-Sünneti'l-Musannefe, (et-Ta'lîkatu'l-Mustazrefe ale'r-Risâleti'l-Mustatrefe ile birlikte), c. III, s. 50.

${ }^{63}$ Zehebî, Târihu'l-i̇slâm, c. XLVIII, s. 351, 352.

${ }^{64}$ Şeyh Abdurrezzak el-Baytar (ö. 1335/1917), Hilyetu'l-Beşer fi Târihi'l-Karni's-Salisi Aşer, nşr. Muhammed Behçet el-Baytar, Dâru Sâdır, 2. Baskı, Beyrut, 1993, c. Il, s. 755.

${ }^{65}$ ibn Kesir, el-Bidâye ve'n-Nihâye, c. XVI, 397. 
getirilmiştir. ${ }^{66}$ Aslen Şamlıdır, uzun yıllar hoca ve şeyhlere intísâp ederek ilim ve tarikat terbiyesi aldı. Pek çok savaşa da katıldı, daha sonra Hakkâri civarında hiç kimsenin yaşamadığı bir yere yerleşti. Kendisinin buraya yerleşmesinden sonra insanlar açısından bir bereket ve emniyet oluştu. Artık insanların yolları bu sarp bölgede kesilmez oldu. İyi bir öğretmen ve Allah için kimseden çekinmeyen biriydi, kendisinden çok kimse istifade etti. Yaklaşık seksen yıl yaşadı. Dünyalık şeylere kıymet vermezdi. Küçük bir tarlası vardı, onu sürer ve onunla geçinirdi. Pamuk eker, onunla kendisine elbise yapardı. Başkasının malından asla yemezdi. Kendisine has virt vakitleri vardı, yanındakilerle yatsı namazını kılar, daha sonra sabaha kadar kimse onu göremezdi. Bir yere uğradı̆̆ında oradaki ahali yalnızca selamını almak için yollara dökülürdü. Hâfız Abdulkadir, bir gün kendisiyle birlikte Musul tarafına gittiğini ve bir manastırı ziyaret ettiğini bildirmektedir. Bu esnada onları iki ruhbanın karşıladığını ve yanına gelerek onun ayağını öptüklerini kaydeder. Sonra bu rahipler bereket için kendilerine dua etmesini istemişler ve içinde ekmek ile bal olan bir tepsi getirdiklerini, duadan sonra teberrüken oradakilerin bunları yediğini söyler. Adî b. Musâfir, çoğu günleri oruçlu olarak birleştirirdi, bu yüzden insanlar onun hiçbir şey yemediğine inanırlardı. Bunu duyduğunda, insanların kötü düşüncelerini bertaraf etmek için onların huzurunda bir şeyler yemiştir. Kerametlerle ve zahidane bir hayat yaşamakla meşhur olmuştu. Kerametlerinden çokça örnekler verilir, Meselâ aslanı çă̆ırdığında aslanın hazır olduğu, denizde fırtına olduğunda dua etmesiyle firtınanın geçtiği aktarılır. Ömer b. Muhammed, ona yedi yıl hizmet ettiğini ve pek çok kerametine şahit olduğunu söyler ve şunları anlatır: Bir gün eline su dökerken ne istediğimi sordu, ben de 'Kur'ân'ı ezberlemek istiyorum, Fatiha ve îhlâs surelerinden başka ezberleyemediğimi" söyledim. Eliyle göğsüme dokundu ve onun yanından ayrılıncaya kadar Kur'ân'ı mükemmel bir şekilde ezberlemiştim demektedir. ${ }^{67}$ Hâfız Abdulkadir, öleceği yıl onun Musul Kalesinin dış tarafında bir kabrin başına gittiğini ve Sultan ve ilin yöneticilerinin, hocalar, şeyhler ve insanların oraya kadar gelerek kendisine eziyet edercesine ellerini öperken gördügünü ifade eder. İnsanlar o kadar çok ziyaretine gelirlerdi ki, kendisi ile insanların arasına bir tel örgü çekmişti ve yalnızca kendisini görmelerine izin vermeye başlamıştı. Bu sebeple kendisine olan bağlılıktan dolayı bazı insanlar haddi aşmaya başladılar, hatta bazıları onu kendilerine kıble yapıp ona dönerek namaz kılmaya başladılar. Yaklaşık doksan yıl yaşadıktan sonra 557/1162 yılında Hakkâri'de vefat etti ve kendisine ait zaviyesine gömüldü. Kabri 817/1414 yılında yakılmıştır. ${ }^{68}$

${ }^{66}$ Ziriklî, el-A'lâm, c. IV, s. 221.

${ }^{67}$ ibnu'l-ìmâd, Sezerâtu'z-Zeheb, c. Vl, s. 300, 301.

${ }^{68}$ Şemsuddin Ebû Abdullah Muhammed b. Ahmed b. Osmân b. Zehebî (ö. 748/1347), Siyeru A'lami'n-Nubelâ, nşr. Şuayb Arnaût, Müessesetu'r-Risâle, ı. Baskı, Beyrut, 1984, c. XX, s. 342- 
3.15. Ebû Muhammed ibrahim b. Dâvud b. Nasr el-Hakkârî ed-Dımaşkî elMukaddesî: Takriben 640/1242 yılında dünyaya geldi. Halep'te Haburî́den kıraat rivayetlerini ders aldı ve daha sonra Hama'ya geçerek bir müddet burada kaldı. Hama'dan da Şam'a geçerek burada kıraat derslerini vermeye başladı ve bir müddet Şam Ümeyye Camiinde sürekli Kur'ân okumak için atandı. Ahmed b. Hanbel'in “Müsned'inin çoğunu Şeyh Şerefuddin el-Ensarîdden ders aldı ve daha sonra kendisi hadis dersleri vermeye başladı. 712/1312 yılında vefat etti. ${ }^{69}$

3.16. Sâlihuddin Kavvâs Sâlih b. Ahmed b. Osmân b. Hamid b. Ali elHakkârî el-Ba'lî: 633/1235 yılında dünyaya geldi. Şair bir zattı. Fakirlerle arkadaşlık yapardı. Rüyaları doğru tabir etmesiyle şöhret bulmuştu. 723/1323 yılında vefat etti. ${ }^{70}$

3.17. Şemsuddin Ebû Abdullah Muhammed b. İbrahim b. Dâvud b. Nasr el-Hakkârî el-Kürdî ed-Dımaşkî: Aşağıda kendisinden söz edeceğimiz Fatıma'nın kardeşidir. 685/1286 yılında dünyaya geldi. et-Takî, el-Vasıtî, Şeref ibn Asâkir ve başkalarından ders aldı. Şam'da Sadakatu'l-Hukmiyye Nezaretine atanmıştır. Şam surlarının dışındaki Şafîi fukahasına ait Kavvasiyye Medresesinde fikıh dersleri veriyor, aynı zamanda Ümeyye Camiindeki $\mathrm{Hz}$. Ali Türbesinde imamlık yapıyordu. et-Tenbih adlı kitabı ezberlemiști. Fetva veren biriydi. Matematik alanında da uzmandı. Kendisinden en son Abdurrahman ỉbn Ömer el-Kubabî el-Mukaddesî icazet almıştı. 759/1358 yılında vefat etti. ${ }^{71}$

3.18. Ahmed b. Ebî Bekr b. Ahmed Şihab Ebû Abbâs el-Hakkârî el-Kürdî ed-Dımaşkî: Mekke'ye gelip yerleşmiştir. "Hâvi"yi ezberledi ve bunu Şam'da İmâd el-Hisbânîye arz etti. ỉbn Umeyle, ỉbn Kevalih, Kemal b. Hubeyb, Cemal el-Bacî ve başka hocalardan Şam, Haşep, Kahire ve ìskenderiye'de ders aldı. Sık sık Mekke'ye dönerdi. Ömrünün son on dört yılını İzz el-i̇sbehânînin ribatında tarikata bağlı olarak yaşadı. Mısır'da kendisine bağlı itibarlı insanlar vardı ve her yıl bunlardan bir kısmı kendisini ziyarete gelirlerdi. 838/1434 yılının Safer ayında Mekke'de vefat etti ve Muallâ mezarlığına defnedildi. ${ }^{72}$

3.19. Ebû Abdullah Muhammed b. Ebî Zühr ỉbn Sâlim b. Ebî Zühr elHakkârî: 655/1257 yılında dünyaya geldi. ibrahim b. Halil ve Necib Abdullatif elHarranînin huzurlarında ders aldı. İmad ibn Abdulhadi, ibn Abduddaim, Diyau Muhammed b. Ömer b. Hoca İmam, kardeşi Ebû Bekr, Şemsuddin Abdurrahman b. Ebî Ömer, yeğeni İzzuddin ibrahim, Kadı Muhyiddin ibn Zekî, Abdulveli ibn Cebbare, Ebû Bekr b. Muhammed el-Herevî, Ahmed b. Cemil, Ahmed b. Şeybân

344; ibn Hallikân, Vefeyâtu'l-A'yân, c. III, s. 254, 255; ibn Kesir, el-Bidâye ve'n-Nihâye, c. XVl, 397; Safedî, el-Vâfi bi'l-Vefeyât, c. XIX, s. 352.

${ }^{69}$ ibn Hacer el-Askalanî, ed-Dürerü'l-Kâmine, c. 1, s. 27.

${ }^{70}$ ibn Hacer el-Askalanî, ed-Dürerü'l-Kâmine, c. Il, s. 196.

${ }^{71}$ ibn Hacer el-Askalanî, ed-Dürerü'l-Kâmine, c. III, s. 279; ibn Râfi', el-Vefeyât, c. Il, s. 216, 217.

${ }^{72}$ Şemduddin Muhammed b. Abdurrahman es-Sehavî, ed-Dav'u'l-Lâmi' li-Ehli'l-Karni't-Tasi', Dâru Kutubi'l-Hayat, Beyrut, ts., c. 1, s. 251. 
ve başkalarının derslerini dinledi. Daha sonra kendisi hadisleri vermeye başladı. İnsanların haklarını gözetir, onu korumaya çok itina gösterirdi, fakirlerin şeyhiydi. Kendi evinde bir zaviyesi vardı. Kendisine bağlı kimseler ve sohbetlerini sürekli dinleyenleri vardı. Şam'da 737/1336 yılının Cumâde'l-ûla ayında vefat etti ve babasının türbesine defnedildi. ${ }^{73}$

3.20. Abdulvâhid b. Ali b. Ahmed Ebû Muhammed el-Kureşî el-Hakkârî elFârikî: 591/1195 yılında dünyaya geldi. Hanbelî mezhebine mensuptu. Musul'da Mismar b. A'veyş ve Hüseyin b. Bar'dan dersler aldı. Genç yaşta Şam'a geldi ve burada Musa b. Şeyh Abdulkadir, Muvaffik b. Kudame, Zeynu'l-Umna ve başkalarından ders aldı. Dini bütün bir âlimdi. Kendisinden de Ebû Muhammed elHarisî, Ebû Haccâc el-Mizzî ve pek çok Mısırlı fakih ders aldılar. Doksan dört yaşında Kahire'de 685/1286 yılının Ramazan ayında vefat etti. ${ }^{74}$

3.21. Ebû Ammâre Hamza b. Ömer b. Ahmed b. Muhammed el-Hakkârî: 713/1313 yılında dünyaya geldi. Kur'ân ve Fıkıh ilmini tahsil etti. ibn Anter ve Zeyneb bint Kemal'den hadis derslerini aldı. 744/1343 yılında Misır'a yolculuk yaptı. 745/1314 yılında Dimyat'tan ayrıldıktan sonra kendisinden bir daha haber alınamadı, dokuz ay sonra bir daha ortaya çıktı. Âlim ve dini bütün biriydi, kitapları yazarak çoğaltırdı. ${ }^{75}$

3.22. Ebû Bekr b. ỉbrahim b. Ma'tûk el-Kürdî el-Hakkârî es-Sâlihî: Ali b. Ebî Bekr el-Harranî̀den hadis dersleri aldı ve ondan aldığı hadisleri derslerinde rivayet etmeye başladı. Hisâr'da 803/ yılında vefat etti. ${ }^{76}$

3.23. Ahmed b. íbrahim b. Ma'tuk el-Kürdî el-Hakkârî es-Sâlihî: Yukarıda kendisinden söz ettiğimiz Ebû Bekr b. ibrahim'in kardeşidir. O da kardeşi gibi Ali b. Ebî Bekr el-Harranî́den hadis dersleri aldı ve ondan aldığı hadislerle dersler verdi. Sehavî, şeyhinin ondan Ebû Nu'aym'in "Sıfatu'l-Cennet"ini ders aldığını söylemektedir. Kardeşi ile aynı yıl içerisinde Ramazan Bayramı günü öğleden sonra vefat etti. ${ }^{77}$

3.24. Ali b. Ahmed b. Yusuf b. Ca'fer Ebû Hasan el-Hakkârî: Bağdat'a gidip Zevzenî ribatına yerleşti. Daha sonra Bağdat'ta birkaç ribatı bizzat kendisi yap-

73 ibn Râfi', el-Vefeyât, c. 1, s. 152.

74 ibnu'l-ìmâd, Şezerâtu'z-Zeheb, c. VII, s. 684; Zehebî, el-iber, c. III, s. 359; Zehebî, Târihu'lislâm, c. Ll, s. 225, 226.

${ }^{75}$ Şemsuddin Ebû Abdullah Muhammed b. Ahmed b. Osmân b. Zehebî (ö. 748/1347), Mu'cemu Muhaddisî́z-Zehebî, nşr. Ravhiyye Abdurrahman es-Suveyfî, Dâru'l-Kutubi'l-ilmiyye, ı. Baskı, Beyrut, 1993, s. 65.

${ }^{76}$ ibn Hacer el-Askalanî, Şihabuddin Ahmed b. Ali (ö. 852/1448), İnbâu'l-Ğumr bi Enbâi'l-Umr, nşr. Muhammed Tevfik Uveyde, ihyau't-Turasi'l-i̇slâmî, Kahire, 1969, c. Il, s. 159; es-Sehavî, edDav'u'l-Lami', c. XI, s. 13.

77 ibn Hacer el-Askalanî, Inbâu'l-Ğumr, c. Il, s. 151; es-Sehavî, ed-Dav'u'l-Lami', c. l, s. 197. Safedî, Ahmed ile kardeşi ibrahim'i aynı kişi zannederek karıştırmıştır. Kendisi, ibn Hacer elAskalanînin bunları karıştırdı̆̆ını söylüyorsa da yanılmaktadır. 
tırdı. Hadis dersleri aldı ve sonra hadis dersleri vermeye başladı. Pek çok hadis Hâfızı öğrenci yetiştirdi. Bir gün Resulullah'ı (s.a.v.) rüyasında medresede bir bahçenin içerisinde gördüğünü söyler. Resulullah'a (s.a.v.) "bana vasiyet et", Resulullah (s.a.v.) de: "Ahmed b. Hanbel'in itikadı ve İmam Şafiĩ nin mezhebini takip et, bid'at ehlinin meclislerinden sakın" diye emir buyurur. 486/ yılının Muharrem ayında vefat etmiştir. ${ }^{78}$

3.25. Cemâluddin Ahmed b. İsmail el-Hakkârî: Bu zatla ilgili elimizde hiçbir bilgi mevcut değildir. Yalnızca Şam'daki Mecnuniye Medresesi'nde İzzuddin Ahmed b. Muhammed b. Ali el-Mevsilîden sonra bu medreseye müderris olarak atandığını biliyoruz. ${ }^{79}$

3.26. Ziyauddin ỉbn Dirbas, Osmân b. İsâ b. Dirbas el-Kadı Ebu Amr elMaranî el-Hakkârî: Allame bir hadis âlimiydi. Kadı Sadruddin Abdulmelik'in kardeşidir. "el-Müzehheb" in yirmi ciltlik çok nefis bir şerhini yazmıştır. Ebu ìshak'ın "el-Luma" adlı eserine de iki ciltlik bir şerh yazmıştır. Döneminde Şafî âlimlerinin en bilgini olarak bilinirdi. 602/1205 yılında vefat etti. ${ }^{80}$ Kudüs'teki Caveliye Medresesi'nde metfun bulunan Dirbas el-Kürdî el-Hakkârî, ${ }^{81}$ bu zatın babası olabilir.

3.27. Ahmed b. Yusuf b. Ali Ebû Abbâs el-Hakkârî el-Cündî: 554/1159 y1lında Şam'da dünyaya geldi. Silefî́den hadis dersleri almıştır. Kendisinden de Zeki el-Munzirî, Cemal Muhammed b. Sabunî ve başkaları hadis derslerini almışlardı. 631/1234 yılında vefat etmiştir. ${ }^{82}$

3.28. Fadl b. Hasan el-Kürdî el-Hakkârî: Şam'ın Sefhu Kasiyun denilen semtinde otururdu. Çok zahit ve ibadete düşkün bir insandı. Daima Câmiu'lCebel'de minberin yanında namaz kılardı, daha sonra buradan ayrılıp Meytur semtindeki Kubbetu'l-Hacc'da namaz kılmaya başladı. Ona niçin eski camiden ayrıldığı sorulduğunda, "bir hadiste komşunun durumunun komşularından sorulacağını duydum, ben Allah'ın beni sizden sormasından korktuğum için ayrıldım" diye cevap vermiştir. Hiç kimseden bir şey almazdı, başkasından bir şey aldığında da helâl olduğuna kanaat getirmedikçe almazdı. Eskiden iyi bir askerdi. Bir gün Salah Musa b. Râcih, Sultan'ın huzurunda ondan söz edince, Sultan da onu ziyaret etmek istemiş, bunu duyduğunda, gece vakti “Allahım kulun Musa'yı benden uzak durması için dilediğin bir şekilde meşgul et" diye dua etmiştir ve

${ }^{78}$ ibn Kesir, el-Bidâye ve'n-Nihâye, c. XVI, s. 138; ibnu'l-Cevzî, el-Muntazam, c. XVIl, s. 7.

${ }^{79}$ Abdulkadir b. Muhammed en-Nua'ymî (ö. 927/1521), ed-Dâris fî Târihi'l-Medaris, nşr. ibrahim Şemsuddin, Dâru'l-Kutubi'l-ilmiyye, 1. Baskı, Beyrut, 1990, c. 1, s. 357.

${ }^{80}$ Safedî, el-Vâfi bi'l-Vefeyât, c. XIX, s. 331.

${ }^{81}$ Muciruddin el-Hanbelî el-Alimî, el-Unsu'l-Celil bi Târihi'l-Kudüs ve'l-Halil, nşr. Adnan Yûnus Abdulmecid Nubâte, Mektebetu Dendis, Amman, 1999, c. ll, s. 38.

${ }^{82}$ Zehebî, Târihu'l-İslâm, c. KLVl, s. 54. 
gerçekten de Sultan çok istediği halde ziyaretine gelememiştir. 644/1246 yılında vefat etmiştir. ${ }^{83}$

3.29. Hıdır b. Muhammed b. Ebî Bekr b. Hıdır Ebû Abbâs el-Hakkârî: Velid b. Utbe b. Ebî Süfyan'ın soyundandır. 573/1177 yılında Mısır'da dünyaya geldi. Şam'da el-Huşu'î̀den hadis dersleri aldı ve daha sonra kendisi ders vermeye başladı. 653/1255 yılının Şaban ayında vefat etti. ${ }^{84}$

3.30. Hıdır b. Halil Ebû Abbâs el-Hakkârî: Sufi bir zattı ve müezzinlik yapardı. Ibrahim es-Senhurîden ders almıştı ve kendisi de bir müddet sonra ders vermeye başlamışıtır. Kendisinden çok kişi ders almıştır, ondan ders alanlardan biri eş-Şerif tir. Kahire'de 673/1274 yılının Recep ayında vefat etmiştir. ${ }^{85}$

3.31.Muhammed b. Ebî Bekr b. Dâvud b. Ebî Bekr Ebû Abdullah el-ìmad b. Hakkârî: Aslen Hakkârînnin İmâdiyye kalesindendi, daha sonra Remle'ye gelerek buraya yerleşmişti ve Şafîi mezhebindendi. Yusuf b. Halil'den ders aldı.. Remle'de $691 / 1292$ yllinda vefat etti. ${ }^{86}$

3.32. Seyyid Abdullah Geylanî es-Semzinî el-Hakkârî: Mevlâna Hâlid elBağdadînin yanında hem ilim hem de tasavvufu tahsil etti, şeyhinin isteği üzerine ilim öğretmek ve tasavvufi irşatta bulunmak üzere memleketi Hakkâri'ye geri döndü. Çok kimse kendisinden istifade etti. 1200/1786 yılında vefat etti. ${ }^{87}$

3.33. Necmuddin Ebû Hasan Ali b. Ibrahim b. Huşşenam el-Kürdî elHakkârî: Halep'te bulunan Cavuliyye Medresesi'nde müderris olarak görev yapmıştır ve burada müderris iken Moğolların istilâsıyla ( muhtemelen 680/128lyılında) medresenin içinde öldürülmüştür. ${ }^{88}$ Bunun dışında kendisi ile ilgili bir bilgiye sahip değiliz.

3.34. Şerefuddin Ebû Abdullah Muhammed b. Ahmed b. Hüseyin elHakkârî: Şeyh Ebû Kasım Yusuf b. Muhammed el-Mehrevanî (ö. 468/1075), meşhur hadis âlimi Hatib el-Bağdadînin hadis ilminin sahih ve garipleri üzerine tahriçte bulunduğu kitabında, bu zattan sık sık söz etmekte, çoğu zaman olduğu gibi bazı rivayetlerle ilgili sözlerini aktarmakta, fakat şahsıyla ilgili herhangi bir bilgi vermemektedir. Zaten müellifin tahriç ettiği “el-Fevâidu'l-Muntehabetu'sSihâh ve'l-Garâib" adlı kitaba esas aldığı nüsha, Muhammed b. Ahmed b. Hüseyin el-Hakkârînnin kendi eliyle çoğalttı̆̆ı nüshadır. Şeyh Ebû Kasım Yusuf b. Muhammed el-Mehrevanî, bu zatın 592/1196 yılının Receb ayında Musul'daki Muzafferiye Daru'l-Hadis'inde, bir başka Hakkârili hadis uzmanı olan ibrahim b. Muhammed b. Ali el-Hakkârî ile birlikte, yine hemşerileri olan Ebû Abdullah Mu-

${ }^{83}$ Zehebî, Târihu'l-ìslâm, c. XLVII, s. 291, 292.

${ }^{84}$ Zehebî, Târihu'l-İslâm, c. XLVIII, s. 147, 148.

${ }^{85}$ Zehebî, Târihu'l-İslâm, c. L, s. 123.

${ }^{86}$ Zehebî, Târihu'l-İslâm, c. Lll, s. 136.

${ }^{87}$ Abdurrezzak el-Baytar, Hilyetu'l-Beşer, c. II, 1013, 1014.

88 ibn Şeddâd, el-A'lâku'l-Hatire, c. 1, s. 277. 
hammed b. Ebi'l-Hakkârî b. Nasrullah b. Ebi Hanife el-Mevsilînden hadis dinlediklerini kaydetmektedir. Keza Muhammed b. Ahmed b. Hüseyin el-Hakkârî, Ebu'lMe'alî Nasrullah b. Selame el-Heytemîden de hadis dersleri almıştır. ${ }^{89}$

3.35. Şeyh Sâlih Veliyyuddin Ebi Abbâs Ahmed b. Abi Bekir b. Abdillah b. Dâvud el-Hakkârî ve Şeyh Ebû Hasan Ali b. Ahmed b. Ebî Bekr b. Abdullah elHakkârî: Selâhaddin Eyyûbî, Küdüs'teki Kırmızı Dağ'daki (Cebelu'l-Hamr) Tur Zeyta denilen ağaçlı bir araziyi Kudüs'ü fethettiğinde Şeyh Sâlih Veliyyuddin Ebî Abbâs Ahmed b. Ebî Bekr b. Abdillah b. Dâvud el-Hakkârî ve Şeyh Ebû Hasan Ali b. Ahmed b. Ebî Bekr b. Abdullah el-Hakkârî arasında eşit şekilde vakfetmişti. $\mathrm{Bu}$ mal onlara ve zürriyetlerine aitti. Vakıf kitabesinde 584 yılının Züll-Hicce ayının on yedisi kaydı düşülmüştür. ${ }^{90}$

\section{4-Hakkârili Kadın Âlimler}

Hakkârili pek çok bayan ilim insanı yetişmiştir. Bunlardan tespit ettiklerimizi aşağıda tanıtacağız. Dikkat edilirse bu bayanların hiç biri Hakkâri'de yetişmemişlerdir. Kendileri Hakkârili olmakla birlikte başka şehirlerde yetişme ve ilim tahsil etme imkânı bulmuşlardır. Neticede Hakkârili olmaları hasebiyle bu beldeye mensup isimlerini duyurmuş, pek çok âlim yetiştirmiş ve ilme hizmet etmiş olmaları bakımından Hakkârililer açısından birer övünç kaynă̆ıdırlar.

4.1. Cüveyriyye bint Ahmed b. Ahmed b. Hüseyin b. Mûsek el-Hakkârî: Genellikle "Ümmü Henâ" diye bilinir. 704/1304 yılının Ramazan ayında dünyaya geldi. Ebû Hasan ibn Savvâftan İmam Neseînnin Sünen'i ile Humeydînin Müsnedini ders aldı. Ali b. İsâ b. Kayyim'dan Sahihu'l-Buharîyi ve Süfyan'ın “Müsned'inin bir cüzünü okudu. Nuri es-Sa'lebîden Ebu Dâvud'un Sünen'inin bir kısmını, Şerif Musa'dan Sahih-i Müslim'i ders aldı. Ibn Şuhne ve Sittu'lVüzera'dan da Sahih-i Buharîyyi okudu. Hasan b. Ömer el-Kürdî̀den Abd ve Darimînin Müsnedlerini, İmam Taînin “Erba'in”ini, Dâvud b. Muhabber'den "el$A k l$ ', Emalî el-Harfiden iki meclis ve Ebu Ali ibn Huzeyme'nin "el-Fevaid'ini üç mecliste okudu. Kendisi hadis dersleri vermeye başladı. Çok sayıda öğrenci yetiştirdi. Kendisinden ders alanlar arasında Ebû Ca'fer b. Kuveyk de vardı. 783/1381 yılında vefat etti. ${ }^{91}$ Meşhur âlim ibn Fakusînin oğlu Muhammed b. Hasan elKureşî ez-Zübeyrî de kendisinden ders alan öğrencilerindendir. ${ }^{92}$

\footnotetext{
${ }^{89}$ Şeyh Ebû Kasım Yûsuf b. Muhammed el-Mehrevanî (ö. 468/1075), el-Fevaidu'l-Muntahabu'sSihah ve'l-Garâib (el-Mehrevaniyat), nşr. Halil b. Muhammed el-Arabî, Dâru'r-Raye, Riyad, 1998, s. 264.

${ }^{90}$ Muciruddin el-Hanbelî el-Âlimî, el-Unsu'l-Celil, c. Il, s. 61 .

${ }^{91}$ ibn Hacer el-Askalanî, ed-Dürerü'l-Kâmine, c. 1, s. 544, 545.

${ }^{92}$ Sehavî, ed-Dav'u'l-Lâmi', c. VIl, s. 221; ỉbnu'l-i̇mâd, Şezerâtu'z-Zeheb, c. VIIl, s. 482; ibn Hacer el-Askalanî, Inbâu'l-Ğumr, c. I, s. 245; Ömer Rıza Kehhale, A'lamu'n-Nisâ fî Âlemi'l-Arab ve'lİslâm, Müessesetu'r-Risâle, Beyrut, ts., c. l, s. 226, 227.
} 
4.2. Esma bint Ahmed b. Ahmed b. Hüeyin b. Mûsek el-Hakkârî: Meşhur bayan âlim Cüveyriyye'nin kız kardeşidir, 615/1218 yılında dünyaya geldi. . ilimde önde gelenlerden biri olmasına rağmen ablasının şöhretine kavuşamamıştır. Ahmed b. İdris b. Meziz el-Hamevĩ nin huzurunda dersler aldı. ibn Asâkir'in Ramazanın Fazileti ile ilgili hadislerini Mekkî b. A'lan'dan ders aldı. Kahire'de hadis dersleri vermeye başladı. Maalesef ölüm tarihini tespit bilmiyoruz ancak Esma'dan Ebu Hamid ibn Zahire'nin 770/1368 yılında ders aldığını biliyoruz. ${ }^{93}$

4.3. Dünya bint Muvaffik Yûsuf b. Süleyman el-Hakkârî el-Mısriyye: ỉbn Kayanînin eşidir. en-Necib'ten hadis dersleri almıştır. ${ }^{94}$ Bu bayan hakkında bundan fazla bir bilgiye sahip değiliz.

4.4. Cuveyriye bint el-Hakkârî: Hadis ilminde uzmandı. Ali b. Nasrullah b. Ömer b. Abdulvahid el-Kureşî el-Mısrî̃den hadis dersleri almıştır. Doksan yaşını aşkın 712/1312 yılında vefat etti. ${ }^{95}$

4.5. Ümmü Muhammed bint Yusuf el-Hakkârî: Bu bayan da hadis ilminde uzmandı. Ebu Tâhir'den ders aldığı hadisleri daha sonra kendisi 714/1314 yılında ders olarak vermeye başladı. ${ }^{96}$

4.6. Fâtıma bint ỉbrahim b. Dâvud b. Nasr el-Hakkârî el-Kürdî: Yukarıda kendisinden söz ettiğimiz ibrahim'in ablasıdır. 683/1284 yılında dünyaya geldi. Fahr'in huzurunda ve ibn Neccâr'dan hadis derslerini aldı ve onlardan hadis rivayet etti. Meşhur muhaddis İmam el-lrakî, ondan hadis dersleri alan öğrencilerindendir. Şam'da 758/1357 yılının Ramazan ayında vefat etmiş ve Bab Sağir kabristanına defnedilmiştir. ${ }^{97}$

\section{5-Hakkârililerin Kurduğu illmi Kurumlar}

Hakkârili âlim ve yöneticilerin kurdukları bazı eğitim ve öğretim kurumları bulunmaktadır. Adî b. Musafir'in Hakkâri'de kurduğu zaviye ve medresesinin dışında burada başka medresenin varlığını tespit edemedik. Ancak değişik şehirlerde Hakkârililerin kurdukları bazı eğitim kurumları mevcuttur. Bunlardan tespit edebildiklerimiz şunlardır.

5.1. Hakkâriye Medresesi: Emir Huşterin Cemaluddin el-Hakkârîyi yukarıda Hakkârili yöneticiler arasında saymadık, zira kendisi ile ilgili bu medreseyi kurduğundan başka bilgi edinemedik. Emir Huşterin'i Hakkâriye Medresesi'nin kurucusu olarak tanımaktayız. Maalesef bu zatla ilgili elimizde yeterli bilgi mevcut

93 ibn Hacer el-Askalanî, ed-Dürerü'l-Kâmine, c. l, s. 360.

94 ibn Hacer el-Askalanî, ed-Dürerül-Kâmine, c. Il, s. 103.

${ }^{95}$ Kehhâle, A'lamu'n-Nisâ, c. 1, s. 228.

${ }^{96}$ Kehhâle, $A$ 'lamu'n-Nisâ, c. V, s. 31.

97 ibn Hacer el-Askalanî, ed-Dürerü'l-Kâmine, c. III, s. 220; ibn Râfi', el-Vefeyât, c. Il, s. 204; Kehhâle, A'lamu'n-Nisâ, c. IV, s. 24. 
değildir. Emir Huşterin Cemaluddin el-Hakkârî, Kahire'de Kasr denilen yerde Şafîler için bir medrese kurmuştur. Bu medrese, genellikle "Hakkâriye Medresesi" olarak tanınmıştır. Aslında bu medrese bütün Mısır'ın Kadı'l-Kudâtı Sadruddin Abdulmelik b. Dirbas'in kardeşi için kurulmuştur. Kadı'l-Kudât Sadruddin'in kardeşi Ziyauddin Ebû Ömer Osmân b. İsâ b. Dirbas kendisine niyabeten Kahire'de kadılık yapıyordu. Ağabeyi Sadruddin ölünce, kardeşi Kadı Ziyauddin Osmân b. ìsâ b. Dirbas kadılıktan azledilir, bunun üzerine Emir Huşterin, Kadı Ziyauddin için bu medreseyi vakfetmiş ve buradaki müderrisliğini de ona vermişti. Kadı Diyauddin 602/1205 yılında Erbil'de öldü. ${ }^{98}$ Kudüs'teki Hakkâriye Medresesi, aslında Daru'l-Hadis olarak işlev görmüştür. ${ }^{99}$ Meşhur hadis âlimi ibn Hacer el-Askalanî, bir müddet Kahire'de Mansuriye Medresesi'nde hadis derslerini verirken aynı zamanda bu medresede de fikı derslerini vermiştir. ${ }^{100}$ İmam Allame Takiyuddin es-Subkî de, bu medresede Hadis derslerini ibn Ensarî adına veren hocalardandır. ${ }^{101}$ Muhammed b. Ahmed b. Muhammed el-Askalanî et-Tuhî, 774/1372 yılında bu medresede doğmuştu. Bu medresenin önünde öğrencilerin su ihtiyacını gidermek üzere bir kuyusu vardı. Ne yazık ki burada doğan bu zat, 852/1448 yılının Receb ayının dokuzunda Perşembe günü medresenin su kuyusuna düşerek vefat etmiştir. ${ }^{102}$

5.2. Bedriye Medresesi: Bu medrese, yukarıda kendisinden söz ettiğimiz Bedruddin el-Hakkârî (ö. 614/1217) tarafından Kudüs'te Şafî̀ fukahası için vakfedilmiştir. ${ }^{103}$ Medrese, Kudüs'te Lu'luiyye Zaviyesi ile Şeyh Muhammed elAramînnin zaviyesinin yakınlarında ve Merzuban'ın hizasındaydı. ${ }^{104}$

5.3. Dâru'l-Hadis Hakkâriye, Bu Dâru'l-Hadis, Hakkârili bir yönetici tarafından kurulduğundan "Hakkâriye" nispetini biz ekledik, eserlerde bu nispet bulunmamaktadır. Söz konusu Dâru'l-Hadis, Calikiyye Türbesinin yanında Kudüs'ün batı tarafinda bulunmaktaydı. Bunu Emir Şerefuddin ìsâ b. Bedruddin Ebû Kasım el-Hakkârî tarafından vakfedilmiştir. Kitabesinde 25 Receb 666/1267 tarihinde vakfettiği kaydedilmiştir. ${ }^{105}$

\footnotetext{
${ }^{98}$ Safedî, el-Vâfi bi'l-Vefeyât, c. 13, s. 197; ibn Hallikân, Vefeyâtu'l-A'yân, c. III, s. 242; Subkî, Tabakatu'l-Kübrâ, c. VIII, s. 338.

${ }^{99}$ Sehavî, ed-Dav'u'l-Lami', c. V, s. 261; Cemaluddin Abdurrahim el-i̇snevî (ö. 772/1370), Tabakatu'ş-Şâfiîyye, nşr. Kemal Yûsuf el-Hun, Dâru'l-Kutubi'l-ilmiyye, Beyrut, 1987, c. l, s. 70.

100 ibnu'l-imâd, Şezerâtu'z-Zeheb, c. VIl, s. 246.

${ }^{101}$ ibn Kesir, el-Bidâye ve'n-Nihâye, c. 14, s. 114.

${ }^{102}$ Sehavî, ed-Dav'u'l-Lami', c. VIl, s. 87, 88.

${ }^{103}$ ibn Kesir ed-Dımaşkî, Tabakatu'l-Fukahâi'ş-Şâfiîyye, c. Il, s. 801, 802; Muciruddin el-Hanbelî elAlimî, el-Unsu'l-Celil, c. II, s. 388.

${ }^{104}$ Muciruddin el-Hanbelî el-Âlimî, el-Unsu'l-Celil, c. Il, s. 47.

${ }^{105}$ Muciruddin el-Hanbelî el-Alimî, el-Unsu'l-Celil, c. II, s. 43; s. 388.
} 


\section{Sonuç}

Hakkâri, bulunduğu coğrafi konum ve fiziki şartlar nedeniyle ilim ve kültür merkezi olmaktan uzak bir mahaldedir. Ancak, Hakkârili insanların ilme olan iştiyak ve merakları, bu beldenin önemli bir ölçüde ilim merkezi olmasına yetmemişse de, ilim elde etmek için gittikleri şehirlerde birer Hakkârili olarak isimlerini duyurmayı başarmış ve ilme önemli hizmetlerde bulunmuşlardır. Hakkârili bu ilim aşı̆̆ı insanların bir kısmı üstlendikleri yöneticilik görevleriyle bu hizmeti üstlenirlerken, diğer bir kısmı da ilim ehli olarak benzer bir yükümlülüğü yerine getirmişlerdir.

ilim tahsil etmede yalnızca Hakkârili erkekler değil, kadınlardan da isimlerini duyurmuş ve tabakat kitaplarına geçmeyi başarmış altı kişiyi bulmak bu açıdan çok önemli ve enteresandır. Zira kadınların ilim elde etmede erkekler kadar uygun bir ortam ve şartların oluşmadığı bir dönemde bunu başarmaları gerçekten her türlü övgüyü hak etmektedir. Bu çalışmamızda bir dönem ilim sahasında Hakkâri'nin ismini duyurmuş kişileri tespit etmeye ve tanıtmaya çalıştık.

\section{KAYNAKÇA}

Ebû Bekr Kâfî, Menhecu'l-Imâmi'l-Buhârî fi Tashihi'l-Ehâdis ve Ta'lilihâ, işraf: Hamza Abdullah elMelyubarî, Dâru ibn Hazm, 1. Baskı, Beyrut, 2000.

Ebu Nu'aym el-i̇sbehânî, Ahmed b. Abdullah b. Ahmed b. İshak el-i̇sbehanî, el-Musnedu'lMustahrec alâ Sahihi İmam Müslim, nşr: Muhammed Hasan İsmail eş-Şafiî, Dâru'l-Kutubi'lilmiyye, 1. Baskı, Beyrut, 1996.

Ebû Tayyib el-Fasî, Muhammed b. Ahmed b. Ali Takiyyuddin el-Mekkî el-Fasî (ö. 832/1429), Zeylu't-Takyîd fi Ruvati's-Sünen ve'l-Esânid, nşr: Kemal Yusuf Hût, Dâru'l-Kutubi'l-ilmiyye, 1. Baskı, Beyrut, 1990.

Hayruddin Ziriklî, el-A'lâm, Kâmûsu Terâcim, Dâru'l-ilim li'l-Melâyîn, Beyrut, 1986.

ibn Asâkir, Hâfız Ebû Kasım Ali b. Hasan b. Hibetullah (ö. 571/1175), Târihu Medineti Dımaşk, nşr: Muhibuddin Ebu Said Ömer b. Garame el-Amrevî, Daru'l-Fikr, ı. Baskı, Beyrut, 1997.

ibn Hacer el-Askalanî, Ahmed b. Ali (ö. 852/1448), Lisânu'l-Mizan, nşr: Abdulfettah Ebu Ğudde, Mektebu Matbuati'l-i̇slâmiyye, 1. Baskı, Beyrut, 2002.

ibn Hacer el-Askalanî, Şihâbuddin Ahmed b. Ali (ö. 852/1448), ed-Dürerü'l-Kâmine fí A'yâni'lMieti's-Sâmine, Daru'l-Cîl, Beyrut, 1993.

ibn Hacer el-Askalanî, Şihâbuddin Ahmed b. Ali (ö. 852/1448), Inbâu'l-Ğumr bi Enbâi'l-Umr, nşr: Muhammed Tevfik Uveyde, Dâru ihyai't-Turasi'l-i̇slâmî, Kahire, 1969.

ibn Hallikân, Ebu'l-Abbâs Şemsuddin Ahmed b. Muhammed b. Ebî Bekr (ö. 681/1282), Vefeyâtu'lA'yân ve Enbâu Ebnâi'z-Zaman, nşr: ỉhsan Abbâs, Daru Sadr, 4. Baskı, Beyrut, 2005.

ibn Kadı Şuhbe, Ebû Bekr b. Ahmed b. Muhammed b. Ömer (ö. 851/1448), Tabakatu'ş-Şafiîyye, nşr: Hâfiz Abdulalim Han, Dairetu'l-Me'arifi'l-Osmâniyye, ı. Baskı, Hind, 1979.

ibn Kesir ed-Dımaşkî, Tabakatu'l-Fukahai'ş-Şafîiyye, nşr: Ahmed Ömer Haşim ve Muhammed Zeynehum Muhammed Azib, Mektebetu's-Sekafeti'd-Diniyye, Kahire, 1993. 
ibn Kesir, İmâduddin Ebu'l-Fida (ö. 774/1372), el-Bidâye ve'n-Nihâye, nşr: Abdullah b. Abdilmuhsin et-Turkî, Dâru'l-Hicr, 1. Baskı, Beyrut, 1997.

ibn Râfi', Takiyyuddin Ebu'l-Me'alî Muhammed b. Rafi' es-Selâmî (ö.774/1372), el-Vefeyât, nşr: Sâlih Mehdî Abbâs ve Beşşar Avvar Ma'ruf, Müessesetu'r-Risâle, 1. Baskı, Beyrut, 1982.

ibn Şeddâd, ìzzuddin Muhammed b. Ali b. ỉbrahim, el-A'lâku'l-Hatîre fi Zikri'l-Ulemâi'ş-Şâm ve'lCezîre, Nşr: Yahya Zekeriya Abbare, el-Vezaretu's-Sakafiyye, Dımaşk, 1991.

ibn Tağriberdî, Cemâluddin Ebu Mehasin Yusuf el-Atabekî (ö. 874/1469), en-Nucumu'z-Zahire $f$ Mulûki Misr ve'l-Kahire, nşr: Muhammed Hüseyin Şemsuddin, Dâru'l-Kutubi'l-ilmiyye, Beyrut, ts.

ibnu'l-Cezerî, Şemsuddin Ebu'l-Hayr Muhammed b. Muhammed b. Ali (ö. 833/1430), Gâyetu'nNihâye fi Tabakati'l-Kurrâ, Dâru'l-Kutubi'l-ilmiyye, 1. Baskı, Beyrut, 2006.

ibnu'l-Esir Ebû Hasan Ali b. Ebi Kerem Muhammed b. Muhammed b. Ebi Kerim eş-Şeybanî (ö. 630/1233), el-Kâmil fït-Târih, nşr. Ebu'l-Fidâ Abdullah el-Kadî, Dâru'l-Kutubi'l-ilmiyye, ı. Baskı, Beyrut, 1987.

ibnu'l-imâd Şihâbuddin Ebu Ferec Abdulhayy b. Ahmed b. Muhammed el-Akrî ed-Dımaşkî (ö. 1089/1676), Şezerâtu'z-Zeheb fi Ahbari Men Zeheb, nşr: Abdulkadir el-Arnaut, Mahmud elArnaut, Dâru ibn Kesir, ı. Baskı, Beyrut, 1986.

ibnu'l-Faradî, Ebu'l-Velid Abdullah b. Muhammed b. Yusuf (ö. 403/1013), Târîhu Ulemâi'lEndelüs: Târihu'l-Ulemâ ve'r-Ruvat li'l-ilm bi'l-Endelüs, nşr: ibrahim el-Ebyarî, Dâru'lKutubi'l-Benanî, 2. Baskı, Beyrut, 1989.

İmâd el-i̇sbehânî, Haridetu'l-Kasr ve Ceridetu'l-Asr, www.al-mostafa.com, (17.02.2011, 22:51).

iSNEVî, Cemâluddin Abdurrahim (ö. 772/1370), Tabakatu'ş-Şafiîyye, nşr. Kemal Yusuf el-Hun, Dâru'l-Kutubi'l-ilmiyye, Beyrut, 1987.

KALKAŞENDî, Ahmed Ali, Subhu'l-A'şâ fî Sinaati'l-inşâ, nşr. Muhammed Hüseyin Şemsuddin, Dâru'l-Fikr, 1. Baskı, Beyrut, 1987.

KAZViNî, Abdulkerim b. Muhammed er-Rafiî el-Kazvinî, et-Tedvin fî Ahbâri Kazvin, nşr. Azizullah el-Attaridî, Dâru'l-Kutubi'l-ilmiyye, Beyrut, 1987.

KEHHÂLE, Ömer Rıza, A'lâmu'n-Nisâ fî Âlemi'l-Arab ve'l-islâm, Müessesetu'r-Risâle, Beyrut, ts.

KETTANî, Ebû Abdullah Muhammed b. Ca'fer er-Risâletu'l-Mustatrefe li Beyani Meşhuri Kutubi's-Sünneti'l-Musannefe, nşr: Muhammed el-Muntasır Muhammed ez-Zemzemî el-Kettanî, Daru'l-Beşairi'l-i̇slâmiyye, Beyrut, 1986.

MiHREVANî, Şeyh Ebû Kasım Yûsuf b. Muhammed (ö. 468/1075), el-Fevaidu'l-Muntehabatu'sSihâh ve'l-Garâib (el-Mihrevâniyât), nşr. Halil b. Muhammed el-Arabî, Dâru'r-Raye, Riyad, 1998.

Muciruddin el-Hanbelî el-Âlimî, el-Unsu'l-Celil bi Târihi'l-Kudüs ve'l-Halil, nșr. Adnan Yûnus Abdulmecid Nubâte, Mektebetu Dendis, Amman, 1999.

Muhammed Ali es-Sellûbî, Selâhaddin el-Eyyûbî ve Cuhuduhu fíl-Kadâi ale'd-Devleti'l-Fâtimiyye ve Tahriri'l-Beyti'l-Mukaddes, Daru'l-Ma'rife, 1. Baskı, Beyrut, 2008.

NUAYMî, Abdulkadir b. Muhammed (ö. 927/1521), ed-Dâris fi Tarihi'l-Medâris, nşr. ibrahim Şemsuddin, Dâru'l-Kutubi'l-ilmiyye, 1. Baskı, Beyrut, 1990.

NUVEYRî, Şihabuddin Ahmed b. Abdilvehhab (ö. 733/1332), Nihâyetu'l-Ereb fi Fununi'l-Edeb, nşr. Abdulmecid Tarhuyeynî, Dâru'l-Kutubi'l-ilmiyye, 1. Baskı, Beyrut, 2004.

SAFEDÎ, Selâhuddin Halil b. Aybek (ö. 764/1363), A'yânu'l-Asr ve A'vânu'n-Nasr, nşr. Ali Ebu Zeyd ve diğerleri, Dâru'l-Fikr, ı. Baskı, Dımaşk, 1998.

SAFEDî, Selâhuddin Halil b. Aybek (ö. 764/1363), el-Vâfi bi'l-Vefeyât, nşr. Ahmed Arnaût ve Türki Mustafa, Dâru ihyai't-Turâsi'l-Arabî, 1. Baskı, Beyrut, 2000.

SEHÂVî, Hâfız Şemsuddin Muhammed b. Abdurrahman (ö. 902/1496), el-Buldâniyât, nşr. Hassan b. Muhammed el-Kattan, Daru'l-Atâ, Suudi Arabistan, 2001. 
SEHAVî, Şemduddin Muhammed b. Abdurrahman, ed-Dav'u'l-Lâmi' li Ehli'l-Karni't-Tâsi', Dâru'lKutubi'l-Hayat, Beyrut, ts.

SuYûTî, Celâluddin Abdurrahman b. Ebî Bekr (ö. 911/1505), Hüsnü'l-Muhadara fî Târihi Misr ve Kahire, nşr. Muhammed Ebu'l-Fadl ibrahim, Daru ihyai'l-Kutubi'l-Arabî, ı. Tab, Kahire, 1967.

Şeyh Abdurrezzak el-Baytar (ö.1335/1917), Hilyetu'l-Beşer fi Târihi'l-Karni's-Salisi Aşer, nşr. Muhammed Behçet el-Baytar, Dâru's-Sadr, 2. Baskı, Beyrut, 1993.

Tâcuddin es-Subkî, Ebu Nasr Abdulvahhab b. Ali b. Abdilkafî (ö.77ı/1370), Tabakatu'ş-Şafiîyyeti'lKübrâ, nşr. Mahmud Muhammed et-Tanahî, Abdulfettah Muhammed el-Hulv, Dâru ihyai'lKutubi'l-Arabî, Kahire, ts.

Yâkut el-Hamevî, Şihabuddin Ebû Abdullah Yâkut b. Abdullah (ö. 626/1229), Mu'cemu'l-Buldan, Dâru Sadır, Beyrut, 1977.

ZEHEBî, Şemsuddin Ebû Abdullah Muhammed b. Ahmed b. Osmân (ö. 748/1347), Târihu'l-islâm ve Vefeyâtu'l-Meşâhir ve'l-A'lâm, nşr. Ömer Abdusselâm Tedmurî, Dâru'l-Kitabi'l-Arabî, I. Tab, Beyrut, 1993.

ZEHEBî, Şemsuddin Ebû Abdullah Muhammed b. Ahmed b. Osmân (ö. 748/1347), el-iber fi Haberi Men Ğaber, nşr. Ebu Hacer Muhammed es-Said b. Besyunî Zağlul, Dâru'l-Kutubi'lilmiyye, 1. Baskı, Beyrut, 1985.

ZEHEBî, Şemsuddin Ebû Abdullah Muhammed b. Ahmed b. Osmân (ö. 748/1347), Siyeru A'lâmi'n-Nubelâ, nşr. Şuayb Arnaut, Müessesetu'r-Risâle, 1. Neşr, Beyrut, 1984.

ZEHEBî, Şemsuddin Ebû Abdullah Muhammed b. Ahmed b. Osmân (ö. 748/1347), Mu'cemu Muhaddisî́z-Zehebî, nşr. Ravhiyye Abdurrahman es-Suveyfî, Dâru'l-Kutubi'l-ilmiyye, ı. Baskı, Beyrut, 1993.

ZUBEYDî, Muhammed b. Muhammed b. Abdurrezzak, Tâcu'l-Arûs min Cevâhiri'l-Kâmûs, Dâru'lHidâye, ts. 